\title{
DE CÁRDENAS A ECHEVERRÍA: LOS 12 PUNTOS DE LA POLÍTICA EXTERIOR DE MÉXICO HACIA LA ESPAÑA DE FRANCO (1936-1975)
}

Carlos Sola Ayape

\begin{abstract}
Mencionar el hecho de que la España franquista no participó activamente en la Segunda Guerra Mundial de lado del nazi-fascismo, como era su deseo, gracias fundamentalmente a la resistencia de la República y del pueblo español que, a lo largo de cuatro años, resistió el embate de las fuerzas franquistas.
\end{abstract}

Manuel Tello Macías, Tlatelolco, 29 de septiembre de 1975.

1. De Tlatelolco a Madrid pasando por Nueva York: A MODO DE INTROITO

EL 29 de SEPTIEMbRE DE 1975, y desde las oficinas centrales de la Secretaría de Relaciones Exteriores de México (SRE), ubicadas en Tlatelolco (Distrito Federal), Manuel Tello Macías, nombrado ese mismo año Director en Jefe para Asuntos Políticos Bilaterales por el canciller mexicano Emilio O. Rabasa, firmó un documento oficial dirigido a Alfonso García Robles, en ese entonces representante permanente de México ante la onu. Con su firma y salida, se iniciaba un estratégico juego de triangulaciones concebido desde Los Pinos -sede residencial del presidente de México- para provocar la salida de Franco del poder, un militar que se hizo con la jefatura del Estado en España tras su triunfo sobre el ejército republicano en la Guerra Civil (1936-1939). 
Como se irá viendo, ésta fue una cuestión de alto nivel presidencial -y hasta personal del máximo dirigente mexicano-, y aquellas tres cuartillas, debidamente escritas y correctamente mecanografiadas, hicieron de puente entre Tlatelolco y Nueva York, aunque teniendo a Madrid -concretamente al Palacio del Pardo, sede habitacional de Franco- en el verdadero punto de mira. Dicho en pocas palabras, aquel "asunto" -acepción empleada para la ocasión- no era otro que una precisa e intencionada relación de "puntos que podrían quedar en la presentación de García Robles", presentación que el canciller mexicano en las Naciones Unidas debía hacer oír por todos los medios a su alcance en dicho organismo internacional. Aquéllos fueron tiempos de acciones y discursos.

A decir verdad, la propuesta desde Tlatelolco era deudora de la rispidez que venía caracterizando en esos años a la particular relación del México posrevolucionario con una de las dos Españas: la franquista. La vieja problemática enquistada en el tiempo había surgido del apoyo del general Cárdenas y del cardenismo a la causa del presidente Manuel Azaña en la Guerra Civil española y, posteriormente, de la recepción del exilio republicano y del reconocimiento oficial de la España Republicana del Exilio en 1945, ya durante el mandato de Manuel Ávila Camacho. Ahora, la recta final del sexenio de Echeverría estaba marcada por un protagonismo presidencial sin precedentes, hasta el punto de encabezar una particular afrenta en contra de Franco y de su régimen manu militari. Recuérdese, por poner un ejemplo, que ya en abril de 1973 el presidente Echeverría había declarado en la Academia de Ciencias Políticas y Morales de París que "a pesar de las décadas transcurridas desde entonces, México sostiene y sostendrá la legitimidad de la República Española y el compromiso solemne contraído de no reconocer a un régimen impuesto por la intervención extranjera". ${ }^{1}$

${ }^{1}$ El Nacional, 12 de abril de 1973, p. 1. Por el lugar donde fueron dichas, las declaraciones de Echeverría buscaban una repercusión especial, no exentas de simbolismo, ya que no hay que olvidar que en París se encontraba la sede oficial de la República Española en el Exilio, en ese entonces presidida por José Maldonado. De cualquier modo, hay que subrayar que la congruencia de sus palabras era plena con respecto a la esencia del discurso político del cardenismo. 
Con estos antecedentes, no sorprende el paso al frente que el presidente Luis Echeverría dio en septiembre de 1975, cuando Franco se vio sumido en el ojo del huracán hasta quedar atrapado en una maraña de críticas recibidas desde diferentes rincones del mundo, con la notoria salvedad del Chile de Augusto Pinochet. El hecho de que la dictadura franquista condenase a pena capital a varios españoles se convirtió en noticia que corrió súbitamente como reguero de pólvora. ${ }^{2}$ El franquismo recuperaba así la fórmula del fusilamiento selectivo para acabar, o cuando menos mitigar, con una desatada ola de atentados terroristas que venía azotando España en ese entonces. ${ }^{3}$ De hecho, la promulgación, el 26 de agosto de ese año, de un duro decreto-ley de represión del terrorismo y el incremento de las medidas administrativas y judiciales contra los llamados delitos de opinión llevaron al país a un auténtico estado de excepción no declarado. Dadas así las cosas, y sometido a críticas cada vez más ácidas desde las filas del propio Movimiento, "el Gobierno decidió dar pruebas de energía". ${ }^{4}$

Así bosquejada, aquella repentina coyuntura histórica se presentaba propicia para hacer múltiples lecturas políticas y hasta

${ }^{2}$ Véase, por ejemplo, The New York Times, 27, 28 y 29 de septiembre de 1975 (pp. 1,13 y $14 ; 1$ y 26 y 1 y 12 , respectivamente).

${ }^{3}$ Lo sorprendente del caso es que aquellas condenas y posteriores ejecuciones quedaron un tanto opacadas por el estruendo internacional que se produjo, fruto del rechazo frontal por buena parte de la comunidad internacional (Parlamento Europeo y Papa Paulo VI, entre otros). Recordemos que fue incendiada la embajada española en Lisboa y se produjo el asalto a la de París, así como la retirada de Madrid de embajadores de 14 países. A su vez, el 1 de octubre la Comunidad Económica Europea decidió interrumpir las negociaciones que venía manteniendo con el gobierno español. "España ante su peor crisis después de la Guerra Civil”, se leía en la prensa mexicana. Véase El Nacional, 29 de septiembre de 1975 , p. 3.

${ }^{4}$ Como recuerda Julio Gil, "el crecimiento de la violencia terrorista de grupos como ETA o el FRAP, enormemente desestabilizadora desde una perspectiva social, añadía argumentos a la crítica ultra al aperturismo y a la exigencia de una política más dura contra la oposición”. Julio Gil Pecharromán, Con permiso de la autoridad. La España de Franco (1939-1975), Madrid, Ediciones Temas de Hoy, 2008, pp. 305 y 314 . 
para emprender acciones diplomáticas de diversa índole. ${ }^{5} \mathrm{~A}$ decir verdad, y para el caso presente, nunca como hasta entonces un presidente mexicano había visualizado tan cercana una previsible caída de Franco. La delicada salud de aquel caudillo -recordemos que Franco murió el 20 de noviembre, es decir, unas semanas después- llevó a algunos líderes internacionales, como Echeverría, a recrear la idea de que la fuerte repulsa internacional y la imposición de determinadas medidas políticas y económicas tomadas en contra de España podían provocar la renuncia de aquel militar octogenario. Y de lograrse tal propósito, la capitalización de tal suceso podía devengar un importante rédito político. Como acertadamente señaló José Antonio Matesanz, "Echeverría vio aquí la oportunidad de dar un golpe sensacional". ${ }^{6}$

Para alcanzar este objetivo y reforzar la iniciativa oficial, el ejecutivo mexicano puso en marcha la articulada maquinaria del Estado mexicano: prensa oficial, Partido Revolucionario Institucional (PRI) y Congreso de la Unión incluidos. Habida cuenta de que se quería lograr un consenso internacional contra Franco, las principales recomendaciones salieron desde la SRE a través de una de sus figuras más representativas: Manuel Tello Macías. Definida la estrategia presidencial, los diferentes actores fueron entrando en escena, uno a uno, con el fin de entablar hilo directo entre Tlatelolco y Nueva York, sede oficial de las Naciones Unidas. Como era de prever, la cancillería mexicana debía asumir buena parte del protagonismo, y desde sus oficinas centrales se pusieron sobre la mesa los argumentos históricos, jurídicos y diplomáticos más convincentes para adornar, con la fuerza debida, los posibles

${ }^{5} \mathrm{Al}$ respecto, véase "Luis Echeverría: el presidente saliente, el último presidente”, en Carlos Sola Ayape, Entre fascistas y cuervos rojos: España y México (19341975), México, Porrúa /Tecnológico de Monterrey, 2008, pp. 146-194; Agustín Sánchez Andrés y Marco Antonio Landavazo, "México y España. Entre la ruptura y la normalización, 1975-1977”, Ciencia Nicolaita, núm. 35, agosto de 2003, pp. 1322; y Marco Antonio Landavazo, "La crisis entre México y España en el ocaso del franquismo”, Secuencia, núm. 38, mayo-agosto de 1997, pp. 95-120.

${ }^{6}$ José Antonio Matesanz, "De Cárdenas a López Portillo: México ante la República Española, 1936-1977”, Estudios de Historia Moderna y Contemporánea, vol. viII, 1980, p. 213. 
discursos diplomáticos. Como se verá en las páginas postreras, aquél no era un "asunto" cualquiera, ya que era mucho lo que estaba en juego.

En este sentido, y de la documentación reunida, ninguna prueba escrita de tanta consideración como el mencionado documento mecanografiado que, elaborado en Tlatelolco, llevaría la firma de Tello Macías. De entrada, y por su origen administrativo, esta fuente primaria alcanza notable notoriedad no sólo por tratarse de un documento oficial, surgido desde el seno de una de las secretarías del Estado mexicano, sino por ser concebido desde la confidencialidad y hasta discrecionalidad para un uso exclusivamente interno. Como ya se mencionó, el destinatario no era otro que uno de los actores más relevantes a la hora de defender los intereses de México en este organismo internacional y, en consecuencia, una de las piezas más operativas en el engranaje de la política exterior mexicana en aquellos años setenta: el representante permanente en la onu. ${ }^{7}$

Como se observa, tanto por su continente como por su contenido, el manuscrito se nos muestra como un testimonio documental importante por cuanto nos ayuda a descifrar las claves de las complejas relaciones entre el México posrevolucionario y la España franquista durante aquellas largas cuatro décadas del siglo xx, esto es, desde aquel 18 de julio de 1936 -día, mes y año del

${ }^{7}$ Recordemos que Alfonso García Robles nació en Zamora (Michoacán) el 20 de marzo de 1911. Tras su licenciatura en Derecho y Ciencias Sociales en la unAM, obtuvo el lauro del Instituto de Altos Estudios Internacionales de la Facultad de Derecho de la Universidad de París (1936) y un diplomado en la Academia de Derecho Internacional de la Haya (1938). En 1939, año del fin de la Guerra Civil española, ingresó al servicio exterior mexicano para desempeñar numerosos cargos. Entre otros, fue asesor y secretario general de la delegación de México que participó en la Conferencia de San Francisco (1945), director en jefe para asuntos de Europa, Asia y África y de Organismos Internacionales (1957), delegado mexicano en diferentes periodos ordinarios de sesiones de la Asamblea General de las Naciones Unidas (1957-1961), representante permanente de México ante las Naciones Unidas (diciembre de 1970) y secretario de Relaciones Exteriores (29 de diciembre de 1975-30 de noviembre de 1976). En octubre de 1982, García Robles obtuvo el Premio Nobel de la Paz por sus esfuerzos diplomáticos en favor del desarme en el mundo. 
estallido de la Guerra Civil española-, hasta fines de septiembre de 1975, a pocos días del fallecimiento de Franco. Recordemos, al respecto, que aquel régimen político emanado de la Revolución Mexicana siempre tuvo por principio rector que su política exterior debía ser una rama privilegiada de ese gran tronco vigoroso que era la política interna del país.

Y en materia de ambos, la "cuestión española" siempre estuvo presente, de una u otra forma, aunque sólo fuera para hacer de ella una estrategia procedimental, capaz de formalizar ese juego cosmético de apariencias calculadas y de máscaras democráticas. Como señala Rafael Loyola, el gobierno mexicano defendió al exilio español como "uno de los tantos artilugios para pulir una imagen de país democrático y respetuoso de los derechos humanos", y todo ello "sin poner en cuestión las relaciones comerciales con la antigua metrópoli”, esto es, con la España franquista. ${ }^{8}$ Para la ocasión, y en palabras de Shapira, durante el sexenio de Echeverría "la inquietud por el destino de la democracia en el extranjero, como se expresó en alusiones críticas a los sucesos de España y de cualquier parte, intentó ayudar a mitigar el impacto del retroceso de la democracia en el país". 9

Más allá de estas consideraciones, lo cierto es que en sólo tres cuartillas, debidamente estructuradas en 12 puntos, la cancillería mexicana reunió un cuerpo de ideas y principios que durante siete sexenios -desde Cárdenas hasta Echeverría- vino dando soporte a la postura oficial de México con respecto al problema español y, en suma, a las dos Españas: la franquista y republicana del exilio. De su presentación, análisis y contextualización nos ocuparemos a continuación, aunque para su mejor comprensión bosquejaremos primeramente las coordenadas históricas del que este singular texto fue deudor.

${ }^{8}$ Rafael Loyola, "Con Franco, la guerra y la moderación se nos atravesaron”, en Mari Carmen Serra Puche; Francisco Mejía Flores y Carlos Sola Ayape (eds.), De la posrevolución mexicana al exilio republicano español, México, FCE, 2011, p. 196.

${ }^{9}$ Yoram Shapira, "La política exterior de México bajo el régimen de Echeverría: retrospectiva”, Foro Internacional, núm. 73, julio-septiembre de 1978, p. 76 . 


\section{El presidente EcheVerría y su afrenta a Franco Y AL FRANQUISMO}

A pesar de la repulsa unánime de la comunidad internacional y de la solicitud generalizada de condonación de penas, aquel sábado 27 de septiembre de 1975, entre las 8 y las 10 de la mañana, fueron "pasados por las armas" -expresión recogida en el parte oficialdos miembros militantes de la banda Euskadi Ta Askatasuna (ETA) y tres del Frente Antirrevolucionario Antifascista y Patriótico (FRAP), todos ellos acusados por el régimen franquista de cometer actos de terrorismo con muertes. De los once condenados en distintos consejos de Guerra -celebrados en Madrid, Burgos y Barcelona, y caracterizados todos ellos por su rapidez y carencia de las más mínimas garantías jurídicas y procesales para los detenidos-, seis de ellos acabaron mereciendo el indulto personal de Franco. ${ }^{10}$ Quienes no corrieron con la suerte de la clemencia y el perdón siempre serán recordados por ser las víctimas de las últimas ejecuciones de la historia de España.

Consumado el hecho, y sin tiempo para la demora, al día siguiente, 28 de septiembre, el embajador Alfonso García Robles ${ }^{11}$

${ }^{10}$ Dichos indultos fueron estratégicamente politizados por los arquitectos del franquismo. En su comparecencia en Televisión Española, el presidente del gobierno español Carlos Arias Navarro recordó ante una audiencia estimada de 20 millones de telespectadores que "en el corazón de todos los españoles y de sus dirigentes hay un hueco para los sentimientos de piedad y bien lo ha demostrado nuestro jefe de Estado llevando su clemencia hasta límites que casi traspasaban las indeclinables exigencias de la justicia”. La Vanguardia, 1 de octubre de 1975, pp. 3 y 4.

${ }^{11}$ Recordemos que García Robles venía ejerciendo su cargo de Representante Permanente de México en las Naciones Unidas desde su nombramiento el 8 de diciembre de 1970 y la presentación de credenciales el 14 del mismo. Su misión llegó hasta finales de diciembre de 1976, cuando el 29 del mismo asumió la responsabilidad suprema en la SRE hasta el 30 de noviembre de 1976. En palabras de Olga Velázquez, "las bases de la formación jurídica internacional de García Robles fueron abrevadas en instituciones europeas. La sensibilidad y el nacionalismo del novel abogado internacionalista no podían eludir el influjo de la cultura occidental, como tampoco fueron ajenos a las formas protocolarias de la diplomacia tradicional europea”. Olga Velázquez, "La pugna por la paz y la polémica ideológica en torno al uso militar de la energía atómica”, en Alberto Enríquez Perea (coord.), Homenaje a Alfonso García Robles, Premio Nobel de la Paz en 1982, México, unam, 2013, p. 267. 
remitió una carta del presidente Luis Echeverría al secretario general de las Naciones Unidas, Kurt Waldheim, secundando todas y cada una de las instrucciones telefónicas recibidas previamente del secretario de Relaciones Exteriores mexicano, Emilio O. Rabasa. El mensaje presidencial combinaba un diagnóstico de la realidad con un ruego petitorio a la comunidad internacional el cual se encaminaba a poner e imponer un cerco sobre la España franquista. Así, a la política tradicional de no reconocimiento al gobierno de Franco, Echeverría acabó añadiendo "a su arsenal de llamados liberal-progresistas un agresivo movimiento antifranquista". ${ }^{12}$ Por eso no fue casual que Echeverría hablase no en su nombre, sino en el de su país, aunque teniendo en cuenta, eso sí, no a su pueblo, sino al pueblo español. He aquí las primeras palabras de su epístola: "México une, vehemente, su convicción y su voz a la comunidad internacional en su condena por las graves y repetidas violaciones a los derechos humanos que ha cometido el régimen dictatorial que, desde la destrucción de la República, ofende al pueblo español". ${ }^{13}$

Siguió, y como era previsible, la remembranza de los tradicionales principios rectores de la política exterior mexicana -ya desde la Doctrina Carranza de aquel 1 de septiembre de 1918-, ${ }^{14}$ y de la necesidad de obrar conforme a la esencia constitutiva de las Naciones Unidas. Reconociendo primero que México había sido siempre defensor de los principios de libre determinación y no intervención en los asuntos internos de los Estados, añade: "Ante la reiterada conducta criminal de la dictadura que agobia

12 Como señala Shapira, "la reacción de Echeverría fue sorprendentemente severa para producir un impacto sobre la opinión pública interna”. Yoram Shapira, "La política exterior de México bajo el régimen de Echeverría: retrospectiva", Foro Internacional, núm. 73, julio-septiembre de 1978, pp. 83 y 84.

${ }^{13}$ El Nacional, 29 de septiembre de 1975, p. 1.

${ }^{14}$ Cabe mencionar que el punto IV de la Doctrina Carranza recogió esta idea toral: "La diplomacia debe velar por los intereses generales de la civilización y por el establecimiento de la confraternidad universal; no debe servir para la protección de intereses particulares, ni para poner al servicio de éstos la fuerza y la majestad de las naciones". Al respecto, véase Antonio Manero, México y la solidaridad americana: la doctrina Carranza, Madrid, Editorial Americana, 1918, 243 pp.; y Blas Urrea, La herencia de Carranza, México, Imprenta Nacional, 1920, 131 pp. 
a España, ahora, como siempre, no quiere ser cómplice de actos contrarios al pacto jurídico en que se funda la existencia de las Naciones Unidas”. Por momentos, y como se verá más adelante, el presente testimonio recordaba la denodada defensa que el presidente Lázaro Cárdenas, por medio de diplomáticos como Narciso Bassols o Isidro Fabela, hizo en los años treinta en un organismo internacional deudor del Tratado de Versalles como fue la Sociedad de Naciones.

Con este introito y estas remembranzas, Echeverría hizo la siguiente solicitud a la comunidad internacional representada en la ONU: "Es el momento en que deben cambiar su actitud todos los países que, en una u otra forma, han mantenido relaciones o han apoyado a la dictadura española, impuesta por el nazi-fascismo, para que hagan una honrada rectificación a su conducta”. Para lograr tal meta, Echeverría pidió al secretario general Waldheim una reunión del Consejo de Seguridad, "con carácter urgente", para que, de acuerdo con los artículos 5 y 6 de la Carta de la onU, se pidiera a la Asamblea General que "el régimen español sea suspendido del ejercicio de los derechos y privilegios inherentes a su calidad de miembro". ${ }^{15}$ Dicho de otro modo, la propuesta del presidente mexicano se cimentó en la idea de recuperar la sentencia dictada en la Conferencia de San Francisco de 1945 -por cierto, y como se verá después, fue un fallo emitido a instancias de la delegación mexicana-, donde la España de Franco quedaría vetada de ingresar en las Naciones Unidas.

$\mathrm{Y}$, sin embargo, y a la sazón de las urgencias, Echeverría fue más allá al no conformarse únicamente con la expulsión de España de la onu, ya que "las consecuencias internas de la dictadura

${ }^{15}$ Los artículos 5 y 6 de la carta constitutiva de la onu advertían de las recomendaciones que el Consejo de Seguridad -órgano rector de la organizaciónpodía hacer sobre la supresión del ejercicio de los derechos y privilegios de un país miembro, llegando incluso a su expulsión de la organización. Sobre el papel, sus cinco miembros permanentes -Estados Unidos, Reino Unido, República Francesa, la URSS y la República China- no parecían estar por la labor de atender, con la seriedad pertinente, a un caso de esta naturaleza. Recuérdese, y como se verá más adelante, que hasta la Unión Soviética votó a favor del ingreso de España -tan franquista y anticomunista- a este organismo internacional. 
franquista [...] acarrearán intervención y la confrontación abierta o disimulada de las grandes potencias, y esto constituye una amenaza a la paz mundial". He aquí su testimonio: "México pide a usted [que] inste a los miembros de las Naciones Unidas a interrumpir totalmente sus relaciones económicas y las comunicaciones ferroviarias, marítimas, aéreas, postales, telegráficas, radioeléctricas y otros medios de comunicación (como la televisión) y a romper con España sus relaciones diplomáticas”. De este modo, y haciendo valer su condición de país miembro, el presidente Echeverría-que el 29 de septiembre ordenaba que México rompiese todos los vínculos comerciales y las comunicaciones con España- pretendió que la ONU se convirtiese en un instrumento internacional de presión diplomática para precipitar el derrocamiento del general Franco y en consecuencia la caída definitiva del régimen franquista en lo que a todas luces presumía ser todo un triunfo político y diplomático. No puede pensarse otra cosa cuando Echeverría sugería a sus pares la imposición de un bloqueo en toda regla no sólo a Franco y al franquismo, sino a España y a los españoles. Aquello iba más allá de levantar una "muralla de hielo diplomático". ${ }^{16}$

Dadas así las cosas, el 29 de septiembre, un día después de conocerse la propuesta de Echeverría -ruego petitorio incluido-, el embajador de España en la onu, Jaime de Piniés, remitió una carta al secretario general Waldheim, primero, para descalificar la nota del presidente mexicano por incurrir en términos "inadmisiblemente injuriosos para el gobierno de un Estado miembro de la

${ }^{16}$ A modo de metáfora, este entrecomillado formó parte de un titular con el que la prensa oficial mexicana describió la naturaleza sui generis de aquella coyuntura histórica. El Nacional, 29 de septiembre de 1975, p. 3. Al día siguiente, también el periódico El Nacional abrió portada con un titular especialmente acorde con las intenciones de Echeverría: "La misma voz, la misma conducta". En columna se decía que el mundo hervía de indignación sobre lo que estaba sucediendo -o por suceder- en España ante el "zarpazo criminal" que pretendía dar Franco, al que tachaban de ser una "fiera" y de ser "el ahijado de Mussolini y de Hitler". Caracterizado así el enemigo, tocaba hacer loa y defensa del régimen posrevolucionario para decir que la vigilia no se había roto y que México había sido "consecuente" y seguía siendo "fiel a sus principios". Y se proponía la siguiente posdata: "Echeverría recoge la bandera enarbolada por Cárdenas. Pide justicia para el verdadero y noble pueblo español”. El Nacional, 29 de septiembre de 1975, p. 1. 
organización" y, después, para catalogar el comportamiento de Echeverría como un gesto de clara injerencia en los asuntos domésticos de un país soberano, como era España, con que violentaba el artículo 2 (párrafo 7) de la Carta de las Naciones Unidas. Era patente que la guerra dialéctica y epistolar estaba declarada.

A la sazón, De Piniés hizo dos acusaciones directas en contra del presidente Echeverría, especialmente porque el gobierno mexicano ya tenía antecedentes de "intervenir en los asuntos internos españoles". La primera, y refiriéndose a la España Republicana del Exilio, para recordar que "una de las formas más flagrantes de hacerlo es el reconocimiento de un pretendido gobierno en el exilio que carece de toda base jurídica o de cualquier apoyo o representación popular" y, la segunda acusación, con manifiestos tintes personales, echando en cara la complicidad de Echeverría en la matanza de la plaza de Tlatelolco del 2 de octubre de 1968, en su condición de secretario de Gobernación a las órdenes del presidente Gustavo Díaz Ordaz. El embajador De Piniés no tuvo reparo alguno en acusar al presidente mexicano de carecer de "estatura moral necesaria" para injerir en asuntos soberanos de otros Estados, por ser el responsable de "lanzar el ejército contra unos estudiantes que trataban de manifestarse en la Plaza Central de Tlatelolco, [...] acción que, como es sabido, produjo un elevadísimo número de víctimas y la indignación mundial". ${ }^{17}$

A la par, el 30 de septiembre el primer ministro del gobierno español, Carlos Arias Navarro, se presentó en Televisión Española, la única existente en aquella España de censura, para denunciar

17 ABC, 30 de septiembre de 1975, p. 13. Este mismo periódico de filo franquista tildó de "estúpido e irresponsable" el ataque de México contra España. $A B C, 1$ de octubre de 1975 , p. 9 . Al respecto, el representante soviético en la oNU recordó de manera intencionada que no había ningún miembro de este organismo internacional que no guardara "esqueletos en su clóset" y que, de empezar a exhibirlos, "el resultado podría ser desastroso". Véase "México y España en la onU. Los esqueletos del clóset”, Proceso, núm. 15, febrero de 1977, p. 53. Desde las oficinas centrales del Partido de Acción Nacional (PAN), partido opositor al PRI, llegó a decirse que "en México habrían bastado sólo dos hechos -Tlatelolco y Jueves de Corpus-, sobre los cuales jamás se hizo justicia, para merecer la suspensión de la ONU". Véase $A B C, 1$ de octubre de 1975, p. 10. 
públicamente "la campaña exterior contra España", provocada por "la intolerable actitud de aquellos países que, con olvido de las más elementales reglas respecto a la independencia y soberanía nacional, han pretendido inmiscuirse en la vida interna de nuestra patria”. Sus palabras siguientes tuvieron esta elocuencia: "De ahí nuestra dolorida sorpresa al advertir cómo regímenes políticos, nada escrupulosos a la hora de adoptar los más expeditivos procedimientos contra los brotes de violencia registrados en sus respectivos países, manifiestan ahora su farisaica indignación contra la legalidad y la justicia españolas". Añadió lo siguiente, señalando claramente con el dedo: "El caso de Méjico, promotor de la inaudita iniciativa de nuestra expulsión de las Naciones Unidas, y de cuyo concepto de los derechos humanos dan buena muestra los espantosos asesinatos de la Plaza de las Tres Culturas en 1968, es el exponente más claro de esta repugnante farsa". ${ }^{18}$

Si Echeverría conocía bien al franquismo, no hay duda de que, a tenor de estos testimonios, el franquismo parecía saber sobradamente de Echeverría y de su pasado reciente. Más allá de si fuera o no responsable de lo acontecido en la Plaza de las Tres Culturas, lo cierto es que el franquismo había acusado a Echeverría de ser el máximo responsable de los hechos. Por eso, las inculpaciones del representante franquista en la onU no debieron ser tema menor ante la inmediata reacción que éstas merecieron del ejecutivo mexicano, comenzando por la elaboración del mencionado manuscrito de Manuel Tello Macías y por la enérgica respuesta del

18 Arias Navarro hizo referencia también al intento de injerencia en los asuntos internos de España, por parte de aquellos países que recientemente habían firmado el Acta final de Helsinki: "Cuando apenas se ha secado la tinta del citado documento, alguno de los países firmantes, con hipocresía sin límites, con audacia intolerable, quebrantan el pacto firmado poniendo en tela de juicio decisiones que son competencia exclusiva de nuestra soberanía”. La Vanguardia, 1 de octubre de 1975, p. 3. Recordemos que del 30 de julio al 1 de agosto de 1975 tuvo lugar en Helsinki (Finlandia) la conferencia sobre seguridad y cooperación en Europa entre Estados Unidos, Canadá, la Unión Soviética y todos los países europeos, incluida Turquía. A su término, y entre los principales puntos del Acta de Helsinki, se encontraban el respeto a la igualdad soberana y a los derechos inherentes a la soberanía, el arreglo de las controversias por medios pacíficos y la no intervención en los asuntos internos de los Estados. 
embajador García Robles ante la secretaría de las Naciones Unidas, de la que se dará cuenta en la parte final de estas páginas. De entrada, y como era de prever, se advierte un coordinado ejercicio diplomático, a buen seguro porque las partes implicadas eran conscientes de que el régimen franquista habría de reaccionar de la forma en que lo hizo.

Mientras tanto, en México, el 29 de septiembre entró en escena uno de los grandes líderes del PRI, Porfirio Muñoz Ledo, en ese entonces presidente del Comité Ejecutivo Nacional. Con motivo de un desayuno de trabajo ofrecido por los diputados priistas de la XLIX Legislatura al Congreso de la Unión, ${ }^{19}$ Muñoz Ledo no desaprovechó la oportunidad para hablar del acontecimiento nacional que estaba en boca de todos y en torno al cual pidió hacer una "reflexión conjunta de militantes partidistas", a saber: "La decisión adoptada por el Presidente Echeverría, el día de ayer, al hacer un llamado al Consejo de Seguridad para que plantee a la Asamblea General de las Naciones Unidas la ruptura conjunta de relaciones diplomáticas y la expulsión del régimen de Franco de la comunidad de naciones civilizadas". Para este dirigente del PRI, la actitud presidencial vino a comprobar cómo "el régimen de la Revolución Mexicana tuvo siempre razón, a lo largo de los decenios”, al ser uno "de los pocos regímenes políticos del mundo que mantuvo el compromiso que las naciones democráticas adquirieron en las vísperas de la Segunda Guerra Mundial y que ratificaron a su término: el de no establecer relaciones diplomáticas con los países que abiertamente habían colaborado con el eje nazi-fascista". Nótese cómo estas palabras estaban en consonancia con lo dictado en San Francisco en 1945, de donde se desprendía que la actuación del presidente Echeverría respondía a razones de congruencia

${ }^{19}$ El Nacional, 30 de septiembre de 1975, p. 7. Muñoz Ledo dedicó sus primeras palabras a José López-Portillo, ya para entonces candidato del PRI para contender en las elecciones presidenciales del año siguiente, para después hablar de aspectos varios como los "principios medulares de nuestra Revolución", del lema del partido "Democracia y Justicia Social" y de unas declaraciones del todavía presidente Luis Echeverría, para quien el futuro de México debía estar vinculado con la "democracia social", la característica esencial de "nuestro sistema político". No hay duda de que Muñoz Ledo ya estaba inmerso en la campaña electoral. 
"revolucionaria". "El régimen de la Revolución Mexicana hizo honor a su palabra", llegó a decir Muñoz Ledo.

De igual modo -seguía la argumentación del líder priista-, "esta decisión se inscribe dentro de los grandes hechos que han dado dignidad a nuestra política exterior", por cuanto "representa un conjunto de soluciones concretas, capaz de salvar, en este momento de crisis, el prestigio de las Naciones Unidas como depositarias de una moral internacional". Asimismo, y a su entender, la decisión del presidente Echeverría señalaba "la coherencia de una política interna y de una política exterior, [ratificando] la decisión del régimen político de la República -que comparte plenamente nuestro Partido- de una lucha global en todos los frentes contra todas las formas de fascismo". Tras estas valoraciones, Muñoz Ledo terminó su intervención pidiendo un "acto de solidaridad con la decisión adoptada por el régimen del Presidente Echeverría”, para poner de manifiesto que el aparato del partido oficial cerraba filas en torno a su presidente, por más de que éste estuviera muy próximo a agotar su mandato.

Tan sólo unos días después, el 7 de octubre, Luis Echeverría se encontraba en Nueva York para comparecer ante el xxx periodo ordinario de sesiones de la Asamblea General de la onu. Su estrategia contra Franco seguía su curso, aunque en esta ocasión lo haría sin intermediarios: la tribuna de oradores del gran organismo internacional estaba también reservada para él. En su largo discurso, el presidente mexicano, además de hablar de su propuesta económica para el tercer mundo, del despilfarro que se venía produciendo en armamentos, de la paz como camino para el desarrollo o de la advertencia sobre los paternalismos y hegemonías económicas en la onU, tuvo también palabras para referirse al caso español, en clave de reafirmación de su estrategia seguida: "Ratifico, con firmeza y serenidad, la petición mexicana, elevada a la consideración del Consejo de Seguridad el día 28 de septiembre próximo pasado, consciente de que técnica y políticamente nos asiste la razón". ${ }^{20}$ Entre sus argumentos, Echeverría volvió a insistir en la idea de que aquellos fusilamientos del franquismo eran fruto

${ }^{20}$ Véase El Nacional, 8 de octubre de 1975, pp. 1 y 6-8. 
de "una reiterada violación de derechos humanos" e incurrían en "la creación sistemática de un clima de confrontación violenta, susceptible de conducir a una fricción internacional y [de] poner en peligro el mantenimiento de la paz en un punto de la tierra que, por ser de interés estratégico, amenaza la seguridad mundial". ${ }^{21}$

A nuestro entender, no le faltaba razón a Luis Echeverría a la hora de afirmar que el régimen franquista venía incurriendo en una reiterada violación de derechos fundamentales, pero sí en su presagio de que aquellas ejecuciones eran una amenaza para la paz y la seguridad mundial o que incluso podían generar una fricción internacional. Por momentos la situación se asemejaba en demasía a aquellos años del cerco internacional contra España tras la segunda gran guerra. Dentro de aquella campaña internacional, recordemos, a modo de ejemplo, que Francia llegó a cerrar sus fronteras a comienzos de marzo de 1946, porque "España [era] un peligro para la paz mundial". ${ }^{22}$

De cualquier modo, y con estos antecedentes, la SRE tomó la decisión de asesorar a su embajador García Robles, quien, dicho sea de paso, tan sólo tres meses después asumiría el cargo de secretario de Relaciones Exteriores, tras la renuncia de Emilio O. Rabasa como canciller de México. ${ }^{23}$ No se oculta que, tras las acusaciones españolas vertidas contra Echeverría, el discurso diplomático debía ser el verdadero escudo protector del presidente mexicano, principalmente para convencer a la comunidad internacional de la pertinencia de su llamado. Como se irá viendo, aquello debía

${ }^{21}$ Con estas palabras Echeverría puso fin a su alusión al caso de España, para hablar después de "la urgencia de actualizar sustancialmente el derecho del mar".

${ }^{22}$ Eran declaraciones del ministro de Exteriores galo, Georges Bidault, después de conocerse el fusilamiento de Cristino García Granda, un héroe de la resistencia francesa que, de manera clandestina, se había internado en España para dirigir la Agrupación Guerrillera de Madrid. Véase Juan Eslava Galán, Los años del miedo, Barcelona, Planeta, 2008, p. 374.

${ }^{23}$ Como se ha dicho más arriba, del 29 de diciembre de 1975 al 30 de noviembre de 1976 Alfonso García Robles asumió la titularidad de la SRE, tras la renuncia al cargo del entonces canciller Emilio O. Rabasa. Entre los logros obtenidos durante aquellos 338 días se encuentran el establecimiento de una zona económica exclusiva de 200 millas náuticas, el énfasis en los temas del Nuevo Orden Económico Internacional, la paz mundial y la cooperación internacional. 
ser, por encima de todo, una exhibición de los tradicionales fundamentos que habían enriquecido el discurso diplomático mexicano con respecto a la cuestión española, apegados todos ellos, según se verá, al Derecho Internacional y a los principios constitutivos de las Naciones Unidas. Habida cuenta de que la solución del caso podía llegar lejos, la SRE se preparó para aportar no pocos fundamentos históricos, jurídicos y diplomáticos a la propuesta mexicana en las Naciones Unidas.

Llegados a este punto, y por razones procedimentales, aquellos 12 puntos que daban cuerpo al documento de Manuel Tello Macías serán agrupados en tres grandes apartados temáticos: 1) orígenes y naturaleza del régimen franquista, 2) postura oficial de México sobre la España franquista y 3) México y sus lazos con el pueblo español. Así, y ante las circunstancias diplomáticas del momento, el documento se remitió a un funcionario del servicio exterior como Alfonso García Robles, una figura clave en la política exterior de Echeverría que no sólo dominaba los entresijos y hasta el modus operandi de la SRE, sino que, debido a sus cinco años como representante de México en la onu, conocía muy de cerca la cultura y hasta el juego de negociaciones que se planteaban a diario en este organismo internacional. Además, durante dicho quinquenio venía conviviendo a diario con la delegación diplomática de la España franquista y, desde su origen, sabía muy bien de todos y cada uno de los pormenores históricos de la llamada Spanish question. No en vano su ingreso en el servicio exterior mexicano tuvo lugar durante el cardenismo, precisamente en 1939, año que marcó el final de la Guerra Civil Española y la llegada de buena parte del exilio español a México.

\section{ORÍGENES Y NATURALEZA DEL RÉGIMEN FRANQUISTA} (1939-1975)

Como era previsible, buena parte de las recomendaciones de la SRE a García Robles estuvieron orientadas a la caracterización precisa del sistema político español. Para ello, varios de los puntos del pliego fueron dedicados a evidenciar el origen y naturaleza 
del régimen político impuesto en España por el general Franco tras la Guerra Civil, haciendo especial hincapié en cuatro coyunturas históricas: a) la Guerra Civil Española (1936-1939), b) la Segunda Guerra Mundial (1940-1945), c) el ingreso de España en la ONU (1955) y $d$ ) la actitud del régimen franquista ante el clamor internacional. Sobre estas cuatro referencias coyunturales se escribieron los apartados 1, 2, 5, 7, 8, 9 y 10 del documento, y que, para una mejor comprensión, iremos presentando y analizando por separado.

\section{a) La Guerra Civil Española (1936-1939)}

Con vistas a las posibles intervenciones de García Robles en la ONU, la cancillería mexicana iniciaba sus puntuales recomendaciones poniendo el acento en los "orígenes del régimen español" -puntos 1 y 2 del documento-, que, como es sabido, hundían sus raíces en el estallido de una guerra fratricida en aquel 18 de julio de 1936, fruto de una sublevación armada de varios militares españoles, entre ellos el general Francisco Franco. De manera particular, se pedía a su embajador que tuviera muy presente, primero, la "invasión de España con fuerzas armadas africanas” y, segundo, y refiriéndose a la Segunda República, la "existencia en España de un régimen legal libremente constituido", haciendo expresa referencia a las instituciones democráticas españolas tras el ocaso de la monarquía borbónica de Alfonso XIII y la recuperación del sistema republicano el 14 de abril de 1931. Asimismo, y no en clave de recomendación sino de aseveración, desde Tlatelolco se decía a modo de sentencia que el régimen de Franco no sólo era "producto de la intervención directa nazi-fascista", sino que el llamado bando nacional pudo ganar la guerra gracias a la "presencia de tropas italianas y alemanas" en territorio español. Con estas puntualizaciones, es importante destacar que las dos primeras tesis de la cancillería mexicana quedaban claramente expuestas sobre la mesa: primera, la internacionalización de una guerra aparentemente civil y nacional y, segunda, el nazi-fascismo como esencia constitutiva y patrón ideológico del régimen franquista. 
Los primeros mensajes para García Robles parecían estar lo suficientemente claros. A la altura de aquel verano de 1936, España tenía un gobierno democrático -legal y legítimamente constituido-, que tuvo que soportar una invasión armada procedente de África y además con efectivos africanos, esto es, extranjeros. ${ }^{24} \mathrm{~A}$ su vez, el bando nacional franquista, así como el posterior régimen político impuesto por el general Franco, contaron en todo momento con el apoyo del nazi-fascismo de Hitler y Mussolini. En pocas palabras, el origen del régimen franquista, todavía en pie tras casi cuarenta años de vigencia, fue producto de la clara conculcación de determinados principios fundamentales del Derecho Internacional -soberanía nacional, no intervención, libre autodeterminación de los pueblos o representatividad democrática-, así como de la esencia constitutiva de la entonces Sociedad de Naciones, organismo internacional -antecedente directo de la ONU- surgido en 1919 tras la Primera Guerra Mundial. ${ }^{25}$

${ }^{24}$ No hay que olvidar que Marruecos fue el campo de entrenamiento no sólo del general Franco, sino de toda una generación de oficiales y suboficiales del ejército español. Como puso de manifiesto Stanley Payne, "en 1936, los oficiales de las bases marroquíes, en su mayoría veteranos en combate, apoyaron la conspiración militar y la subsiguiente rebelión mucho más que cualquier otro grupo dentro del ejército". Después, unos 70000 marroquíes, alrededor de $7 \%$ de las tropas nacionales, cruzaron el Estrecho para luchar bajo el mando de Franco. Stanley Payne, 40 preguntas fundamentales sobre la Guerra Civil, Madrid, La Esfera de los Libros, 2006, pp. 355-364. Al respecto, y entre otros, véase también Mohammad Ibn Azuz Hakim, La actitud de los moros ante el Alzamiento: Marruecos, 1936, Málaga, Algazara, 1997, 220 pp.; y José Luis de Mesa, Los moros y la Guerra Civil española, Madrid, Actas, 2004, 320 pp.

${ }^{25}$ Un año después del "alzamiento nacional”, Franco hizo las siguientes declaraciones al Leipziger Illustrierte Zeitung, justificando no sólo la insurgencia armada, sino también la pertinencia de la guerra: "Luchamos por librar a nuestro pueblo de las influencias del marxismo y del comunismo internacionales, que se introdujeron en nuestro país para hacer de España una sucursal del bolchevismo moscovita. Queremos salvar por esta lucha los valores morales, espirituales, religiosos y artísticos creados por el pueblo español a lo largo de una gloriosa historia”. En diciembre de 1938, en esta ocasión en declaraciones al Journal de Genève, Franco dijo esto: "Luchando contra el comunismo, creemos prestar un servicio a Europa, ya que el comunismo es un peligro universal". Véase Pensamiento político de Franco (I), Madrid, Ediciones del Movimiento, 1975, p. 51. 
En este sentido, y de los muchos testimonios reunidos, ninguno tan claro y contundente como aquél de Isidro Fabela, delegado mexicano en aquella Liga de las Naciones, cuando el 28 de septiembre de 1937, un año y medio después del estallido de aquella guerra española, dijo lo siguiente desde la tribuna de oradores: "Existe en España un ejército extranjero perfectamente organizado, con sus jefes respectivos, también extranjeros. [...] Según nuestra opinión, la violación de la integridad territorial comienza desde el momento mismo de la invasión independientemente del resultado final de ésta”. En cuanto a la agresión a la independencia política de España, el delegado Fabela, recogiendo el sentir de su presidente Cárdenas, comentó lo siguiente: "Para nosotros no hay la menor duda: existe una agresión a la independencia política hispana desde el momento en que, interviniendo en sus asuntos interiores, potencias extranjeras apoyan a una facción sublevada contra el Gobierno Constitucional a fin de hacer triunfar una ideología política determinada". Y añadió: "Esa agresión va aún más lejos y resulta más evidente cuando se niega al pueblo español el derecho incontestable y soberano de escoger su propio estatuto político". ${ }^{26}$

Así presentada, ésta fue una de las tesis que con más ahínco defendió el gobierno cardenista, según la cual el bando sublevado venía contando con el favor de las potencias fascistas europeas, haciendo de aquélla no una guerra estrictamente local o doméstica, sino totalmente internacionalizada. No en vano, muchos años después, el 20 de noviembre de 1975, tras conocerse el fallecimiento de Franco, el secretario de Gobernación mexicano, Mario Moya Palencia, hizo la siguiente declaración ante los medios de comunicación: "La tesis de que en España hubo una guerra civil es muy discutible. El pueblo luchó por la subsistencia de los principios de la República y padeció no bajo las balas de sus hermanos, sino bajo toda la parafernalia militarista del Eje que estaba entonces en formación. Los campos de España fueron campos de experimentación de las armas hitlerianas y mussolinescas". ${ }^{27} \mathrm{~A}$

${ }^{26}$ Isidro Fabela, Por un mundo libre, México, Ediciones de la Secretaría de Educación Pública, 1943, pp. 49-55.

${ }^{27}$ Y añadía: "Ya se estaba escenificando en 1936 el gran drama que después 
pesar de los años de distancia entre ambos testimonios, era evidente que para el régimen político mexicano detrás del triunfo de Franco y el franquismo se encontraban las fuerzas ocultas de una ideología como el fascismo que, dicho sea de paso, acabaría arrastrando al mundo a la guerra más devastadora que la humanidad ha conocido hasta la fecha.

\section{b) La Segunda Guerra Mundial (1940-1945)}

En el punto 5 de su documento, Manuel Tello Macías instaba al embajador García Robles a "mencionar el hecho de que la España franquista no participó activamente en la Segunda Guerra Mundial de lado del nazi-fascismo, como era su deseo [sic], gracias fundamentalmente a la resistencia de la República y del pueblo español que, a lo largo de cuatro años, resistió el embate de las fuerzas franquistas, debilitándolas a tal grado que, al término de la Guerra Civil y principios de la Segunda Guerra Mundial, no estaban en condiciones de participar en acciones bélicas fuera de las fronteras". Agregó a continuación: "Subrayar que todo lo anterior obedeció a la resistencia de la República y del pueblo español”.

No faltaba razón a la cancillería mexicana al señalar el estado de ruina y penuria que padeció España tras aquella guerra que vio su final el 1 de abril de 1939, cuando Franco leyó su último parte de guerra y anunció desde Burgos lo siguiente: "En el día de hoy, cautivo y desarmado el Ejército Rojo, han alcanzado las tropas nacionales sus últimos objetivos militares. La guerra ha terminado". Aquello tenía lugar apenas unos meses antes de que Adolf Hitler desencadenase su ofensiva invasiva contra Polonia, que, a la postre, acabaría gestando el nuevo conflicto internacional. Como apostilla Paul Preston: "por encima de todo, la neutralidad de Franco se debió a la calamitosa situación económica y militar de una España hecha

Europa y el mundo entero iban a padecer, y se estaba haciendo un ensayo totalitario que culminó con la imposición de Franco en el poder en 1939”. Véase José Antonio Matesanz (comp.), México y la República Española. Antología de documentos, 1931-1977, México, Centro Republicano Español de México, 1978, p. 442. 
añicos por la Guerra Civil, desastre del que el Caudillo obtuvo enorme provecho". ${ }^{28}$

En efecto, es preciso recordar que, durante los primeros meses de la Segunda Guerra Mundial, la postura oficial del gobierno de Franco quedó alineada a la neutralidad, misma que cambió a la de "no beligerancia activa" el 12 de junio de 1940, tras conocerse la entrada de Italia en el conflicto dos días antes. ${ }^{29}$ Meses después, el 23 de octubre de 1940, y en la ciudad francesa de Hendaya, la entrevista entre Franco y Hitler, acompañados por sus ministros de Asuntos Exteriores -Ramón Serrano Suñer y Joachim von Ribbentrop, respectivamente-, tuvo como primer resultado el que España no entrase a la guerra en calidad de beligerante. ${ }^{30}$ De todos modos, no hay que olvidar que de Hendaya también salió el compromiso de Franco para formar un cuerpo de voluntarios españoles -la División Azul- y ayudar a los ejércitos alemanes en su ofensiva contra la Unión Soviética, tal y como así sucedió en la batalla de Krasny Bor o en el sitio de Leningrado. Para la ocasión, se llegaron a movilizar cerca de 47000 oficiales, con un saldo posterior de 5000 pérdidas humanas y cerca de 9000 heridos en combate. ${ }^{31}$ Paradójicamente, aquellos soldados españoles prestaron juramento para luchar no en favor del nazismo, sino en contra del comunismo, un matiz que advertía en ese entonces de las intenciones estratégicas de Franco pensando en una futura derrota de la Alemania nazi. ${ }^{32}$

${ }^{28}$ Paul Preston, Franco: Caudillo de España, Barcelona, Grijalbo, 1994, p. 659.

${ }^{29} \mathrm{Al}$ respecto, véase Jaume Miravitlles, Los comunicados secretos de Franco, Hitler y Mussolini, Barcelona, Plaza \& Janés, 1977, 264 pp.

${ }^{30}$ Sobre el contexto y sus particularidades, véase Stanley G. Payne, Franco y Hitler: España, Alemania, la Segunda Guerra Mundial y el holocausto, Madrid, La Esfera de los Libros, 2008, 473 pp.; y Stanley G. Payne y Delia Contreras, España y la segunda guerra mundial, Madrid, Editorial Complutense, 1996, 194 pp.

${ }^{31}$ Entre otros, véase José Antonio Vidal y Gadea, Breves notas sobre la División Azul, Alicante, García Hispán, 1991, 74 pp.; Sergio Alegre, El cine cambia la historia: las imágenes de la División Azul, Barcelona, PPU, 1994, 327 pp.; Jorge Martínez Reverte, La División Azul: Rusia (1941-1944), Barcelona, RBA, 2011, 587 pp.; y Xavier Moreno Juliá, La División Azul. Sangre española en Rusia, 1941-1945, Barcelona, Crítica, 2006, $788 \mathrm{pp}$.

${ }^{32}$ Unos años después, el diario falangista Arriba calificaba a la División Azul de "empresa española, falangista y humana" y la concebía como "una empresa univer- 
A pesar de estas circunstancias, la España franquista abandonó su postura de "no beligerancia" en 1943 para declararse neutral en el conflicto, de tal modo que Franco se presentaba ante los de adentro y los de afuera como un héroe camaleónico capaz de moverse entre el Eje y los aliados. ${ }^{33}$ Lo cierto es que, una vez terminada la guerra, y ya en el marco de la posguerra, Franco hizo de su neutralidad un verdadero estandarte al servicio de su propaganda mediática. De nuevo, Preston nos recuerda lo siguiente: "El fin de la guerra en Europa fue recibido con los más exaltados panegíricos al 'Caudillo de la Paz', por la sabiduría y firmeza que le había permitido ofrecer a España el don de la paz. [...] La neutralidad española en la Segunda Guerra Mundial sería ensalzada durante los siguientes treinta años como el logro más grande de Franco". ${ }^{34}$ Para el caso que nos ocupa, es importante resaltar el afán de la cancillería mexicana por desmantelar la tesis de la neutralidad que desde el fin de la segunda guerra venían defendiendo los arquitectos del franquismo. ${ }^{35}$ En pocas palabras, Franco había sido un aliado de Hitler, con que quedaba remarcada una de las tesis preferenciales de México, defendida desde la presidencia del general Cárdenas: la complicidad ideológica del régimen de Franco con la matriz ideológica del nazi-fascismo.

\section{c) El ingreso de España en la ONU en 1955}

Otra de las coyunturas señaladas en el documento de Tello Macías guardaba relación con el ingreso de España en las Naciones

sal, adelantada en 20 años al destino de Occidente [que] formó en línea de combate frente a Rusia, a la culpable Rusia, [...] el enemigo de la civilización cristiana”. Arriba, 13 febrero de 1962, p. 10.

${ }^{33}$ Preston, op. cit., p. 602.

${ }^{34}$ Ibid., p. 659.

35 Por poner un ejemplo, en mayo de 1946 Tomás Suñer, subsecretario de Asuntos Exteriores de España, declaró durante su visita a Estados Unidos lo siguiente: "Nuestra neutralidad ha sido en su conjunto de positivo benéfico para las Naciones Unidas. Fue seria, correcta, firme e inquebrantablemente mantenida por Franco". Arriba, 6 de mayo de 1946, p. 1. 
Unidas, hecho éste que se produjo a fines de 1955. Así, y siguiendo con su concisa lista de recomendaciones, la SRE señalaba en el punto 7 del documento la pertinencia de "destacar el hecho de que se logró su ingreso formando parte de un paquete”. Esta observación es importante, por cuanto no hay que olvidar que tanto el México de Echeverría como la España de Franco no sólo poseían en ese entonces sillón en las Naciones Unidas, sino que presumían de voz propia en el ágora de este gran organismo internacional. Y esto así, a pesar de que las razones que motivaron su ingreso tuviesen naturaleza bien distinta. Si bien México fue país fundador, al ser partícipe activo en la Conferencia de San Francisco de 1945, España tuvo que esperar una década para lograr su ingreso, un tiempo considerado de cuarentena por tratarse de un país -así se interpretó- cuyo régimen político era heredero del nazi-fascismo. ${ }^{36}$

La observación que desde Tlatelolco se le hacía a García Robles bajo ningún concepto era fortuita. Ciertamente, España había logrado su ingreso en la onu formado parte de un bloque o "paquete" de países, de tal modo que su entrada al organismo se había hecho no de forma individual, donde hubiera sido posible revisar con detenimiento la pertinencia de su caso, sino de manera conjunta. ${ }^{37}$ No se oculta, sin embargo, que el enunciado venía a cuestionar implícitamente la carga de legitimidad que avaló en su

${ }^{36} \mathrm{Y}$ así lo ratificaron en agosto de 1945 los tres grandes -Estados Unidos, Reino Unido y la Unión Soviética- en la conferencia de Potsdam (Alemania), cuando se negaron a apoyar la candidatura de ingreso de España en la onU por tener un gobierno "establecido con el apoyo de las potencias del Eje" y, en consecuencia, por no poseer, "vistos sus orígenes, su naturaleza, su pasado y su asociación estrecha con los países agresores, las calificaciones requeridas para justificar su admisión”. Al respecto, véase Enrique Moradiellos García, "Potsdam, 1945: el franquismo en entredicho”, Claves de Razón Práctica, núm. 92, 1999, pp. 54-60.

37 "Tal mezcolanza en el enlistado, países capitalistas como comunistas, hacía tanto más difícil un consenso global en el ámbito del Consejo de Seguridad visiblemente enfrentado. Sea como fuere, fue evidenciándose cada vez con más realismo y pragmatismo político la necesidad de una transacción en bloque o 'paquete' (package) en la que si unos cedían, también los otros se verían obligados a ceder". Alberto José Lleonart y Amsélem, "El ingreso de España en la onU: obstáculos e impulsos", Cuadernos de Historia Contemporánea, núm. 17, 1995, pp. 114 y 116. 
día el mencionado ingreso de España. ${ }^{38}$ Era como recordar que éste se había producido no por méritos propios, sino por razones superiores vinculadas, principalmente, con los intereses estratégicos de las dos grandes potencias en liza: Estados Unidos y la Unión Soviética. ${ }^{39}$ Recordemos que el 14 de diciembre de 1955, y tras la previa recomendación del Consejo de Seguridad, la Asamblea General de la ONU $-555^{\mathrm{a}}$ sesión plenaria- decidió admitir como miembros a 16 países: Albania, Jordania, Irlanda, Portugal, Hungría, Italia, Austria, Rumania, Bulgaria, Finlandia, Ceilán, Nepal, Libia, Camboya, Laos y España. ${ }^{40}$

Para la ocasión, recuérdese también que todo comenzó en San Francisco en los estertores de la segunda gran guerra. Como se verá más adelante, el 19 de junio de 1945 -vísperas de la batalla de Berlín que, a la postre, anunciaría la derrota del nazismo- Luis Quintanilla presentó una moción en lo tocante a la admisión en la ONU de los nuevos miembros. En esencia, el delegado mexicano solicitaba poner a consideración de la comunidad de países repre-

38 "La ONU era consciente de que cuantos más Estados miembros fueran accediendo en su seno tanto más grande sería, si no su poder, sí su prestigio y esferas de influencia. Apuntalar por tanto a las Naciones Unidas, aumentando su número, era un objetivo en ese tiempo. Todo ello jugaba en favor de la esfera española”. Alberto José Lleonart, España y oNU - VI (1952-1955), Madrid, Consejo Superior de Investigaciones Científicas, 2002, pp. 103 y 104.

${ }^{39}$ En palabras de Armero, la solicitud de ingreso por parte de España se presentó tras conocerse el "acuerdo entre caballeros" entre Estados Unidos y la Unión Soviética, en función del cual España aseguraba su entrada junto con otros países más. José Mario Armero, La política exterior de Franco, Barcelona, Planeta, 1978 , p. 159.

${ }^{40}$ El 23 de septiembre de 1955, España presentó su solicitud de admisión como miembro de las Naciones Unidas, acompañada por una declaración en la que aceptaba las obligaciones contenidas en la Carta. Después, el ingreso de España en este organismo internacional fue celebrado como una victoria para el franquismo. No obstante, Franco vio rechazados sistemáticamente sus intentos posteriores de meter a su España en la entonces Comunidad Económica Europea -actual Unión Europea-, en el Consejo de Europa o en la otan. De los primeros estudios en los años cincuenta, véase Manuel de la Calzada, "España y los organismos especializados de la onu", Revista de Política Internacional, núm. 6, 1951, pp. 109-115; y Luis García Arias, "La admisión en bloque en la onU y el ingreso de España", Revista de Política Internacional, núm. 24, 1955, pp. 21-43. 
sentantes que toda solicitud de entrada "no podrá aplicarse a Estados cuyos regímenes fueron establecidos con la ayuda de las fuerzas militares de países que han luchado contra las Naciones Unidas, mientras que estos regímenes permanezcan en el poder". La propuesta mexicana finalmente salió adelante y así quedó plasmada en el capítulo II (artículos 4, 5 y 6) de la carta constitutiva de las Naciones Unidas. El efecto no podía ser más inmediato y hasta contundente en lo referente a la España franquista. Dicha declaración cerraba las puertas de su entrada a la onU, al ser declarado el franquismo un régimen político cómplice con el nazi-fascismo. ${ }^{41}$

Para los intereses de Franco, tuvo que llegar el 4 de noviembre de 1950 cuando la Asamblea de las Naciones Unidas declaró rescindidas las sanciones internacionales que desde 1946 pesaban onerosamente sobre el gobierno de Madrid, en el entendido de que "el establecimiento de relaciones diplomáticas y el intercambio de embajadores y ministros con un gobierno no implica juicio alguno sobre la política nacional de este gobierno". ${ }^{42}$ Asimismo, también el 4 de noviembre se revocaba la recomendación encaminada a impedir que España fuese miembro de los organismos internacionales establecidos por las Naciones Unidas o vinculados a éstas. A partir de ese momento, y en cascada, las cosas fueron acomodándose, una a una, para los intereses del franquismo, empezando por el progresivo retorno de los embajadores a Madrid a lo largo de 1951. Después, y entre otros hitos destacados, el 12 de diciembre de 1952 España ingresaba en la Unesco, el 7 de mayo de 1954 en la Unicef y, en junio de 1955, la onu aceptaba que España enviase a un "observador permanente" -aunque sin derecho a

${ }^{41}$ Una de aquellas frecuentes valoraciones de la prensa franquista del momento decía lo siguiente, y además en titulares y en portada: "La ofensiva internacional del odio contra España alcanza ahora el paroxismo. España lucha bravamente contra un mundo que le echa en cara las taras que a él lo enlodan”. Arriba, 4 de mayo de 1946, p. 1.

42 Véase Matesanz (comp.), México y la República Española, p. 372. Recordemos que la recomendación de retiro de embajadores y ministros acreditados en Madrid sería aprobada el 12 de diciembre de 1946. De cualquier modo, las embajadas siempre permanecieron abiertas, aunque atendidas por funcionarios de menor rango. 
voz ni voto-, que le permitiría mantener contactos oficiales y oficiosos no sólo con las delegaciones de los Estados miembros, sino también con altos funcionarios de la propia organización. Para la ocasión, la persona elegida fue Juan Sebastián de Erice. ${ }^{43}$

Dadas así las cosas, no hay que olvidar que aquéllos eran tiempos de una Guerra Fría cada vez más tensa y bipolar. Como se ha dicho, la solicitud de España iba acompañada de otras candidaturas. ${ }^{44}$ La negociación para su admisión se hizo entre bastidores bajo el compromiso de las dos grandes potencias de no vetar a ninguna de ellas y de procurar un ingreso equitativo de países vinculados con ambos bloques. ${ }^{45}$ Como puso de manifiesto Alberto José Lleonart, "era evidente que la Guerra Fría incidía en el bloqueo de solicitudes en la ONU, apadrinadas unas por Washington y otras por el Kremlin. El Consejo de Seguridad y la Asamblea General era como cajas de resonancia de todo lo que ocurría en

${ }^{43}$ Véase, entre otros, Florentino Portero, Franco aislado. La cuestión española (1945-1950), Madrid, Aguilar, 1989, 422 pp.; Alberto José Lleonart y Amsélem, “España y la onv: la 'cuestión española' (1945-1950)", Revista de Política Internacional, núm. 152, 1977, pp. 27-45; Xavier Pons Ràfols (coord.), España y la oNU: 50' aniversario, Barcelona, Icaria Editorial, 2005, 407 pp.; y Pedro A. Martínez Lillo, "La política exterior de España en el marco de la Guerra Fría: del aislamiento limitado a la integración parcial en la sociedad internacional, 1945-1953", en Javier Tussell, Juan Avilés y Rosa Pardo (eds.), La política exterior de España en el siglo XX, Madrid, UNED-Biblioteca Nueva, 2000, pp. 323-340.

${ }^{44}$ La primera conformación de aquel paquete incluyó a 18 países candidatos. Cuando todo indicaba que la propuesta saldría adelante, la reunión del Consejo de Seguridad del 13 de diciembre de 1955 sirvió para que la China nacionalista presentara su veto a la entrada de la República Popular de Mongolia. En respuesta, la URSS vetó a los Estados que conformaban el bloque occidental, aunque, al día siguiente, el delegado soviético presentó la propuesta de dejar fuera a Mongolia y a Japón, dando el consentimiento para el ingreso de los otros dieciséis, una resolución que finalmente fue aceptada y aprobada por los miembros del Consejo. En cuanto al caso de España, la URSS acabó aceptando su ingreso, primero, como moneda de cambio para que entraran los cuatro Estados de la Europa del Este y, segundo, para ejercer un cierto control, y hasta supervisión, sobre los acuerdos que España estaba teniendo con Estados Unidos, ya que la URSS temía que España pudiera sembrarse de arsenales nucleares.

45 Antonio Fernández y Juan Carlos Pereira, "La percepción española de la ONU (1945-1962)", Cuadernos de Historia Contemporánea, núm. 17, 1995, pp. 137 y 138. 
el exterior". ${ }^{46}$ Finalmente, España recibió el voto favorable de 10 países del Consejo y una abstención, la de Bélgica. Después, en la votación realizada en la Asamblea General la candidatura española obtuvo 55 votos a favor, ninguno en contra y dos abstenciones, las de Bélgica y México, ambas por razones bien distintas. Si, en el caso de la primera, se debió a la presencia en territorio español de León Degrelle, político belga vinculado con el nazismo, protegido por el franquismo y reclamado por la justicia de Bélgica, en el caso de México las motivaciones estuvieron vinculadas con el tradicional rechazo a la dictadura franquista y con el reconocimiento que venía haciendo, sexenio tras sexenio desde 1945, al gobierno de la República Española en el Exilio.

Sin embargo, es importante subrayar que con su abstención México no votó en contra del ingreso de España en la onU, como en principio era de esperar. En la Memoria de la Secretaría de Relaciones Exteriores de ese año se encuentra la explicación a este hecho, aparentemente contradictorio: "Nuestra delegación normaba su actitud según el principio de universalidad, con el propósito de contribuir a la mejoría de las relaciones internacionales y convencido de que la fórmula global contenida en dicho proyecto es la única que permite contar, en breve plazo, con la cooperación de países cuyo ingreso en las Naciones Unidas ayudará a realizar los propósitos de la Carta”. ${ }^{47}$ Para la ocasión, México condicionaba su posición en contra de la dictadura franquista a la progresiva mejoría de las

46 "En la medida en que el mundo se adentraba más y más en la Guerra Fría, ya no era tan sólo el interés convencional del gobierno de España por pertenecer a la Organización, sino también el de ésta por España. Una vez más estaba en juego la división del mundo y, en especial, el papel protagónico de la comunidad occidental, la OTAN en primer término, con fondo amarillo de la guerra de Corea, susceptible de extenderse a otras regiones". Alberto José Lleonart y Amsélem, "El ingreso de España en la onu: obstáculos e impulsos”, Cuadernos de Historia Contemporánea, núm. 17, 1995, pp. 102 y 110.

47 Memoria de la Secretaría de Relaciones Exteriores, 1955 (II), México, 1956, pp. 31-33. Véase también "Informe sintético núm. 65 sobre las actividades políticas de las Naciones Unidas durante el período de dos semanas, comprendido entre el 4 y el 17 de diciembre de 1955", documento firmado por el entonces embajador mexicano en la onU, Rafael de la Colina. Archivo Histórico Genaro Estrada, expediente XII-269-1. 
relaciones entre países en aquel enrarecido marco internacional. De todos modos, y como apunta Julio Gil, no deja de ser curioso que el Estado miembro al que le tocó, por turno, proponer la candidatura de la España franquista para su ingreso en la onU fuera la Unión Soviética. ${ }^{48}$

\section{d) La actitud del régimen franquista ante el clamor internacional}

El último de los cuatro grandes apartados del documento Tello Macías, donde se venía caracterizando al régimen franquista, estaba vinculado con las repercusiones que estaba despertando entre la comunidad internacional la ya comentada sentencia a muerte de varios militantes de ETA y del FRAP. En el punto 10, se le recordaba a García Robles que el de Franco era "un régimen sordo a la opinión pública mundial", donde "la disidencia se combate con el garrote y no con la razón”. ${ }^{49}$ Después de tal aseveración, era oportuno recordar a su embajador en la onU -puntos 8 y 9- que debía insistir en sus comparecencias públicas en el hecho de la permanente "conducta anti-demócrata del régimen español", capaz de faltar al respeto a los "más elementales derechos humanos". Como se verá más adelante, el interés de Echeverría por la defensa de los valores democráticos, la paz y hasta los derechos humanos iba más allá de su afán por enterrar el pasado de Tlatelolco, ya que aquel embate podía devengarle importantes dividendos políticos. Y, mientras tanto, nada como mostrar y demostrar que su activismo en contra de la dictadura franquista estaba conforme a la tradición política del México posrevolucionario.

Lo cierto es que el 1 de octubre de 1975 el general Franco se asomó a los balcones del Palacio Real de Madrid ante la multitud concentrada, y estratégicamente convocada en la plaza de Oriente,

48 Julio Gil Pecharromán, Con permiso de la autoridad. La España de Franco (1939-1975), Madrid, Ediciones Temas de Hoy, 2008, p. 114.

${ }^{49}$ El periódico oficialista El Nacional recogió las declaraciones de los principales líderes mundiales. Uno de los titulares, con el que abrió portada, era significativo: "Una Europa indignada ante los fusilamientos ve próximo el derrumbe del fascismo español”. El Nacional, 28 de septiembre de 1975, p. 1. 
para desempolvar su vieja retórica política sobre los sempiternos enemigos de España -de su España, entiéndase-. Entre vítores, pancartas de apoyo y saludos fascistas de la concurrencia, Franco hizo su particular lectura de lo que venía sucediendo, y donde México llevaba la voz cantante, para decir que aquélla era una orquestada campaña internacional, producto de "una conspiración masónica-izquierdista de la clase política, en contubernio con la subversión terrorista-comunista en lo social". ${ }^{50}$ Para entonces, sus días de vida estaban contados, y aquélla acabó siendo su última comparecencia pública.

\section{Postura oficial de MéXico sobre la España franquista}

A tenor de las páginas precedentes, se ha visto cómo la primera de las estrategias de la SRE estuvo relacionada con la necesidad de evidenciar el origen y naturaleza del régimen de Franco, así como sus rasgos característicos, entre otros y a su entender, su manifiesta vinculación con el nazi-fascismo, la carencia de valores democráticos o la falta de respeto a los derechos humanos más elementales. El afán por la caracterización era manifiesto, algo nada nuevo si tenemos en cuenta que aquéllos eran argumentos y hasta epítetos utilizados por México sobre el franquismo ya desde los tiempos del presidente Lázaro Cárdenas en la lejana década de los años treinta. ${ }^{51}$

De cualquier modo, y especialmente con el afán de salir al paso de las críticas vertidas en contra del presidente Echeverría -por parte, y entre otros, del embajador español Jaime de Piniés-, la SRE se encargó de recordar a García Robles que el presidente de México bajo ningún concepto actuaba por improvisación, sino plenamente consciente de su misión y conforme a los principios rectores que constituían desde años atrás la postura oficial mexicana con

${ }^{50}$ Véase, por ejemplo, $A B C, 2$ de octubre de 1975, p. 21.

${ }^{51}$ El 1 de enero de 1938, en el mensaje a la Nación con motivo del Año Nuevo, el presidente Cárdenas hizo una especial alusión a las dictaduras que, "por razón de su propia esencia, carecen de derecho para arrogarse en forma absoluta la dirección de la vida interior de los pueblos”. Lázaro Cárdenas, Ideario político, México, Ediciones Era, 1972, p. 297. 
respecto a las dos Españas. Así, y en este rubro, las recomendaciones para su embajador en las Naciones Unidas quedaron agrupadas en tres grandes apartados: a) La posición vertical de México sobre el régimen franquista, $b$ ) México y su defensa de la República española en la Sociedad de Naciones y c) la lucha de México para evitar el ingreso de España en las Naciones Unidas. Al igual que en el bloque anterior, cada rubro será presentado y analizado por separado. Vayamos por partes.

\section{a) La "posición vertical" de México sobre el régimen franquista}

En el punto 3 del corto pero explícito manuscrito de la SRE, Manuel Tello Macías pidió a Alfonso García Robles que en sus participaciones en la onU hiciera especial hincapié en la "posición vertical de México a lo largo de cuarenta años", una metáfora que formaba parte del discurso oficial desde que Lázaro Cárdenas se posicionó en torno a la problemática española. De dicha recomendación, se desprenden dos importantes valoraciones: primera, que la actuación del presidente Echeverría estaba a la altura de una postura que México había madurado con respecto al franquismo desde el estallido mismo de la Guerra Civil española y, segunda, que, lejos de precipitaciones e improvisaciones, esa "posición vertical" venía madurándose desde hacía cuarenta años, con la consiguiente aprobación y aceptación de cada uno de los presidentes mexicanos. ${ }^{52}$ En pocas palabras, aquélla era una cuestión de Estado, larvada en el tiempo.

Como en el resto de los casos, la advertencia de Tello Macías a García Robles no era gratuita. El mensaje venía a decir que ya desde tiempos de Lázaro Cárdenas (sexenio 1934-1940) se había forjado una postura en torno al régimen franquista sustentada en

52 Sobre el significado y rédito políticos, así como las dimensiones de esta "posición vertical”, véase Carlos Sola Ayape, "El presidente José López-Portillo y la reanudación de las relaciones hispano-mexicanas (marzo de 1977), Historia del presente, núm. 16, 2011, pp. 113-126; y "Sobre fórmulas y puntos de ruptura: el manejo diplomático en la normalización de las relaciones entre México y España (1975-1977)", Foro Internacional, vol. 51, núm. 2 (204), 2011, pp. 271-303. 
principios fundamentales del Derecho Internacional, en diferentes leyes y tratados internacionales y, finalmente, en los preceptos constitutivos de aquello que se llamó el "nacionalismo revolucionario". 53 A su vez, aquello era una decisión surgida durante el cardenismo pero ratificada después por todos y cada uno de los presidentes que le sucedieron en la silla presidencial. No se oculta que, al hacerlo así, uno de los mayores réditos políticos obtenidos de esta postura provenía del tributo y reconocimiento al verdadero referente iconográfico de aquel México posrevolucionario: el general michoacano Lázaro Cárdenas. ${ }^{54}$

Recuérdese que el 20 de agosto de 1936, tan sólo un mes después de aquello que los franquistas bautizaron como el "glorioso alzamiento nacional”, el presidente Cárdenas tenía muy clara cuál debía ser la actitud de su ejecutivo. He aquí el testimonio: "El gobierno de México está obligado moral y políticamente a dar su apoyo al gobierno republicano de España, constituido legalmente y presidido por el señor don Manuel Azaña. [...] Además, el gobierno republicano de España tiene la simpatía del gobierno y sectores revolucionarios de México". ${ }^{55}$ Después, y como se verá a continuación, Cárdenas acudió a sus diplomáticos para defender la causa de la República de Azaña desde la

53 Véase, entre otros, David Brading, Los orígenes del nacionalismo mexicano, México, Era, 1993, 141 pp.; y Augusto Gómez Villanueva, Nacionalismo revolucionario. Orígenes socioeconómicos de la doctrina internacional de la Revolución Mexicana, México, Miguel Ángel Porrúa, 2010, pp. 87 ss.

${ }^{54}$ Véase "La gestión política del priismo del affaire de México con Franco en el marco de la Guerra Fría”, en Carlos Sola Ayape, Entre fascistas y cuervos rojos: España y México (1934-1975), México, Porrúa /Tecnológico de Monterrey, 2008, pp. 87-138.

55 Lázaro Cárdenas, Obras I - Apuntes, 1913-1940 (I), México, unam, 1972 , pp. 254-355. El 1 de septiembre de 1936, con motivo de la lectura de su segundo Informe de Gobierno, Cárdenas dijo esto ante el Congreso de la Unión: "El Gobierno de España solicitó de nuestro Gobierno [...] la venta de pertrechos de guerra, solicitud que fue atendida poniendo desde luego a su disposición en el puerto de Veracruz 20 mil fusiles de siete milímetros y 20 millones de cartuchos de fabricación nacional”. Los presidentes de México ante la Nación. Informes, manifiestos y documentos de 1821 a 1966 (IV), México, Imprenta de la Cámara de Diputados, 1966, p. 56 . 
tribuna -y trinchera- de la Sociedad de Naciones. ${ }^{56}$ Uno de ellos, Narciso Bassols, pronunció estas palabras en el foro ginebrino -era el 2 de octubre de 1936-: "Apoyado en sólidas bases jurídicas y de comprensión del problema del gobierno español -pues México ha sufrido en el curso de su historia el azote de cuartelazos antisociales-, el gobierno de México definió desde luego su política de cooperación material para el gobierno legítimo de España, que tenía enfrente el hecho crudo de una sublevación militar". 57

Pocos años más tarde, y unas semanas después de asumir el cargo (1 de diciembre de 1940), el nuevo presidente, Manuel Ávila Camacho, fijó la posición de su gobierno con respecto al problema del exilio español y, por ende, del régimen franquista. Sus convicciones católicas hicieron pensar en un posible giro en la política mexicana con respecto a otro católico como Franco, aunque muy pronto aquellas dudas quedaron disipadas. Un decreto presidencial del 21 de enero de 1941 sirvió, primero, para agradecer a su predecesor Cárdenas -por "haber querido ofrecer hospitalidad tan amplia a los refugiados españoles"- y, segundo, para hacer saber que el pueblo y el ejecutivo mexicanos - "impulsados por sentimientos de profunda simpatía" hacia aquéllos-, ratificarían su compromiso de "recibir con positiva complacencia en suelo mexicano, sin distinción de sexos y edades, de cualquiera filiación política o religiosa,

${ }^{56}$ El 14 de abril de 1972, con motivo del XLI aniversario de la proclamación de la Segunda República Española, Horacio Flores de la Peña, entonces secretario del Patrimonio Nacional, recordó esto: "Lázaro Cárdenas, interpretando el sentir de nuestro pueblo, instruyó a nuestros diplomáticos para salvar ante todo, el mayor número de vidas españolas. No es necesario reiterar cuán fructuosa fue esa acción para el país y para las causas democráticas y nacionalistas del mundo". Matesanz (comp.), México y la República Española, p. 475. Véase Isidro Fabela y Luis I. Rodríguez, Diplomáticos de Cárdenas: una trinchera mexicana en la Guerra Civil (1936-1940), Madrid, Trama Editorial, 2007, 180 pp.

57 Véase el discurso completo en Narciso Bassols, Obras, México, FCE, 1964, pp. 392-394. Sobre la ayuda material mexicana al bando republicano español, véase, por ejemplo, Mario Ojeda Revah, México y la guerra civil española, México, Turner, 2005, $341 \mathrm{pp}$. 
a todos los españoles". ${ }^{58}$ Después, y como veremos, Ávila Camacho acabaría siendo un actor determinante en la defensa del exilio en la Conferencia de San Francisco y en la reconstrucción de sus instituciones republicanas en suelo mexicano en aquel verano de 1945 .

Siguiendo con la posición vertical, en mayo de 1947 y desde Washington, el nuevo presidente, Miguel Alemán (sexenio 19461952), declaró que, con respecto al régimen de Franco, "el criterio de México está bien determinado", descartando cualquier posibilidad de cambio en la postura oficial adoptada por Cárdenas y ratificada después por Ávila Camacho. ${ }^{59} \mathrm{Y}$ es que la sombra del cardenismo parecía ser demasiado alargada. ${ }^{60} \mathrm{El} 1$ de noviembre de 1956, el propio "tata” Cárdenas escribió una carta a Luis Quintanilla, en ese entonces embajador de México en la Organización de Estados Americanos (Washington), para decirle, entre otras cosas, lo siguiente: "A los interesados en las relaciones con el gobierno de Franco les queda lo que muy bien expresaste a tu amigo el embajador de Brasil: 'Franco no es eterno; España lo es. Cuando el caudillo desaparezca del escenario político, México restablecerá con honra sus relaciones diplomáticas"'. ${ }^{61}$

Por eso, y ya en el contexto histórico que se aborda en estas páginas, el 30 de septiembre de 1975, el diputado del PRI, Abraham Talavera López, aseveró lo siguiente: “Al asumir una actitud valiente, [...] Luis Echeverría está recogiendo la mejor tradición de nuestro movimiento social: la tradición de Lázaro Cárdenas" ${ }^{62}$ Sin entrar en otras valoraciones, al menos en este rubro, la posición vertical fue una las contribuciones más importantes de aquellos gobiernos revolucionarios y, sin duda, una de las grandes

58 Memoria de la Secretaría de Relaciones Exteriores, septiembre de 1940-agosto de 1941, México, sRe, 1941, pp. 153-157.

${ }^{59}$ Matesanz (comp.), México y la República Española, p. 386.

${ }^{60}$ Carlos Sola Ayape, "El régimen presidencialista mexicano ante el primer franquismo (1939-1955)”, en Abdón Mateos y Agustín Sánchez-Andrés (eds.), Ruptura y transición. España y México, 1939, Madrid, Eneida, 2011, pp. 185-212.

${ }^{61}$ Lázaro Cárdenas, Epistolario de Lázaro Cárdenas (II), México, Siglo XXI, 1974-1975, p. 14.

${ }^{62}$ Matesanz (comp.), México y la República Española, p. 422. 
notoriedades de las peculiares relaciones bilaterales entre México y España durante el siglo xx. Como se verá a continuación, la defensa de esta posición vertical tuvo en los foros internacionales uno de sus principales escaparates. Si Franco sobrevivió a siete presidentes mexicanos, todos y cada uno de ellos hicieron de aquella postura el pórtico desde donde vieron y concibieron a aquel dictador y a su dictadura durante cuatro largas décadas.

\section{b) México y su defensa de la República española en la Sociedad de Naciones}

Como decimos, y tras el estallido de la Guerra Civil, una de las principales estrategias del México cardenista fue salir en auxilio de la España republicana a través de la defensa de sus causas en un organismo internacional como la Sociedad de Naciones. La palabra y la acción se pusieron al servicio de un aliado que se encontraba al otro lado del Atlántico. Por eso, los discursos de los delegados mexicanos residentes en Ginebra -como Narciso Bassols o Isidro Fabela- constituyen buena parte de la arqueología documental de las relaciones hispano-mexicanas del siglo xx. ${ }^{63} \mathrm{De}$ ahí que no fuera casual que Manuel Tello Macías recordase a García Robles -punto 4- el capítulo de la defensa mexicana a la España republicana en este foro internacional, en especial, las intervenciones del embajador Isidro Fabela.

A este respecto, recordemos que a principios de 1937, poco antes de su partida a Europa, el presidente Cárdenas instruyó a Fabela sobre los puntos que debían nutrir sus participaciones en la

${ }^{63}$ En palabras de Luis Ochoa Bilbao, y haciendo referencia a la Guerra Civil española, "los discursos de Isidro Fabela siguen siendo unas piezas únicas respecto a la no intervención y a la autodeterminación de los pueblos. [...] Semejantes principios doctrinarios de la política exterior difícilmente podían ser cuestionados por una intelectualidad mexicana que participaba activa y entusiastamente en la defensa del país ante el mundo". Luis Ochoa Bilbao, "Intelectuales y política exterior: el caso mexicano, siglos xx y xxı", en Paulino Arellanes Jiménez (coord.), Escenarios, actores y conflictos internacionales, México, Grupo Editorial Patria, 2008, p. 190. 
ginebrina Sociedad de Naciones. En esencia, y por encima de todo, México debía seguir siendo "un Estado fiel" a la Liga, un defensor de "cualquier país que sufra agresión exterior de cualquier potencia” y, específicamente en el conflicto español, "el gobierno mexicano reconoce que España, Estado miembro de la Sociedad de Naciones, agredido por las potencias totalitarias, Alemania e Italia, tiene derecho a la protección moral, política y diplomática, y a la ayuda material de los demás Estados miembros". ${ }^{64}$

En esta línea, el 1 de septiembre de 1937, y con motivo de la lectura de su tercer Informe de Gobierno, el presidente Lázaro Cárdenas recordaba ante el Honorable Congreso de la Unión que el 31 de marzo de ese año había remitido una nota a la Sociedad de Naciones donde advertía sobre "la conveniencia de interpretar la neutralidad internacional en casos como el de España, conforme a los principios del Pacto Constitutivo de la Liga”. Y esto era así porque era preciso establecer "una distinción entre los Gobiernos legítimos agredidos, a los que debe proporcionárseles el apoyo a que tienen derecho, y los grupos agresores, a los que resulta indebido facilitar elementos destinados a continuar y volver más sangrienta la lucha". ${ }^{65}$

Teniendo conocimiento de las palabras de su presidente, unos días después, el 20 de septiembre, el delegado Isidro Fabela subió a la tribuna de la XVIII Asamblea General de la Liga sin otro propósito que el de recordar "la dolorosa situación" que vivía España por una cruenta guerra impuesta "contra su voluntad" y para declarar que "era peligroso sustraer a la jurisdicción de la Sociedad de

${ }^{64}$ Isidro Fabela, Cartas al presidente Cárdenas, México, Altamira, 1947, pp. 3-5. Haciendo alusión a esta carta, Isidro Fabela confesó años después lo siguiente: "El año de 1937 nuestro gran expresidente de la República, mi ilustre amigo general don Lázaro Cárdenas, al nombrarme delegado permanente de México en la Sociedad de Naciones, me puntualizó sus ideas, a las que debería sujetar mis actos diplomáticos”. Fernando Serrano Migallón, Con certera visión: Isidro Fabela y su tiempo, México, FCE, 2000, p. 276. Sobre las precisiones y valoraciones en torno a estas instrucciones presidenciales, véase Agustín Sánchez Andrés y Fabián Herrera León, Contra todo y contra todos. La diplomacia mexicana y la cuestión española en la Sociedad de Naciones, Tenerife, Idea, 2011, pp. 265 y 271.

65 Los presidentes de México ante la Nación. Informes, manifiestos y documentos de 1821 a 1966 (IV), México, Imprenta de la Cámara de Diputados, 1966, p. 68. 
Naciones ciertos problemas -como el de España-, cuya resolución es urgente para la consolidación de la paz". El paso del tiempo acabaría dando la razón a su consideración final: "Creemos que, si al iniciarse la intervención extranjera en España, en vez de ignorarse las realidades, se aceptan aplicándoles el Pacto rigurosamente, esa intervención habría cesado, y la Sociedad de Naciones, defendiendo los principios del Derecho de Gentes, habría alcanzado un resonante triunfo". ${ }^{66}$ Nótese el hecho de que Fabela daba por sentado que lo que estaba sucediendo en España era una intervención extranjera de la Alemania de Hitler y de la Italia de Mussolini a favor del bando nacional franquista, tal y como lo pensaba el presidente Cárdenas, así como lo pensaría el resto de los presidentes mexicanos que le sucedieron.

En la misma línea, el 28 de septiembre de 1937, en esta ocasión ante la VI Comisión de la Asamblea General de la Liga, Isidro Fabela leyó uno de sus más célebres discursos en torno a la problemática española, haciendo a la par un ejercicio de sustentación de la posición oficial de México con respecto a este problema. ${ }^{67}$ Primeramente, Fabela comenzó su alocución con un diagnóstico de la realidad internacional, afirmando que España estaba siendo víctima "de una agresión exterior", violentando el contenido del artículo 10 del Pacto de la Sociedad de Naciones, y que, por tanto, "debe quedar sometida a las obligaciones que de dicho artículo se desprenden". "Tal agresión -dijo Fabela-, no evitada oportunamente por la Sociedad de Naciones, se ha transformado en guerra ilegal". Para reforzar esta tesis de la ilegalidad, el delegado mexicano dijo que, tras su incursión en territorio español, "soldados ex-

66 "En segundo lugar -añadía Fabela- en vez de decir que se ha evitado la guerra, ¿no sería más justo decir que se prolongó en España y se aplazó en Europa?”. Esta predicción del delegado mexicano no fue errática, refiriéndose a Francia e Inglaterra y a su falta de determinación al escudarse en el Comité de No Intervención: "Temo muy seriamente que algún día su abandono los obligue, en condiciones más difíciles, a emplear esa fuerza a la que tanto temieron recurrir". Isidro Fabela, Por un mundo libre, México, Ediciones de la Secretaría de Educación Pública, 1943, pp. 41-48.

${ }^{67}$ Isidro Fabela, Por un mundo libre, México, Ediciones de la Secretaría de Educación Pública, 1943, pp. 49-55. 
tranjeros han bombardeado por mar, tierra y aire ciudades abiertas, a fin de hacer triunfar por el terror la ideología política que no tienen derecho a imponer fuera de su propia patria". Sobre las motivaciones de esta intervención, Fabela no tuvo dudas al respecto: "En el caso de España, la agresión tiene precisamente por objeto servir de instrumento a una política nacional, pues con ella se trata de instituir un régimen político sobre el cual, naturalmente no nos pronunciamos, pero que corresponde a la voluntad nacional de la nación española, ya que es el pueblo español, y solamente él, quien debe escoger su régimen político que le convenga".

Las intervenciones de Isidro Fabela en Ginebra no cayeron en saco roto, al menos al otro lado del Atlántico. Conocida la noticia, el presidente Cárdenas le escribió personalmente: "Me he enterado con satisfacción de su vigoroso discurso pronunciado en la 18 . $^{\mathrm{a}}$ sesión general de la Liga de las Naciones, en el cual se expone claramente la actitud del Gobierno de México ante los problemas internacionales de mayor gravedad actual". Para la ocasión, Cárdenas volvió a insistir en una de sus tesis preferenciales: "La Liga constituye un organismo previsor de conflictos entre las Naciones y un Tribunal Supremo ante el cual pueden acudir los pueblos injustamente atacados para exponer sus derechos, reclamar justicia y obtener el fallo de la opinión universal, que siempre condena las violencias de la soberanía nacional y, mucho más, si el atropello se intenta sobre los pueblos débiles". ${ }^{68}$ Por eso, la carta que Fabela escribió a Cárdenas, con fecha de 11 de noviembre de 1937, sonó más a sentencia que a diagnóstico. Sus palabras fueron elocuentes sobre el destino que le deparaba a aquella República de Manuel Azaña: "La suerte del gobierno español podría modificarse de manera radical si la Gran Bretaña y Francia rectificaran su política

68 Cárdenas volvió a ratificar su compromiso con la defensa de la legitimidad, operatividad y prestigio de un organismo internacional como la Sociedad de Naciones, nacida del Congreso de Versalles a comienzos de 1919: "Esta supremacía de la voluntad popular, la democracia auténtica, el respeto a la integridad de cada país y el propósito sincero de pacificaciones, constituyen la esencia de la doctrina real e internacional de México, que nos empeñamos en hacer oír desde la tribuna de la Liga”. Lázaro Cárdenas, Epistolario de Lázaro Cárdenas (I), México, Siglo Xxi, 1974, pp. 307 y 308. 
hacia España, en forma legal y decisiva” ${ }^{69}$ Algo que, por otra parte -añadimos para la ocasión-, nunca sucedería. ${ }^{70}$

Superada la Guerra Civil española, y cuando el mundo se debatía en los campos de batalla de otra guerra -la segunda mundial-, de nuevo Isidro Fabela, en esta ocasión en un acto del 3 de noviembre de 1942 organizado por los partidos republicanos españoles en el Palacio de Bellas Artes de la capital mexicana para conmemorar el aniversario de la muerte del presidente Azaña, hizo la siguiente valoración ante la concurrencia: "Cuando llegué a Ginebra a principios de 1937, la guerra civil de España se había transformado ya en una guerra internacional: Hitler y Mussolini, enemigos de la democracia y en particular de la República Española, habían intervenido militarmente en España para ponerse de parte de los rebeldes no sólo violentando la integridad territorial de un Estado soberano y la fe de tratados solemnes pisoteados por ellos, sino quebrantando sagrados principios del Derecho de Gentes”. En cuanto a la posición de México frente al caso de España, Fabela recordó que ésta fue "clara y neta". He aquí sus palabras: "El Gobierno del señor Presidente, general don Lázaro Cárdenas, no sólo condenó desde su nacimiento la rebelión franquista, sino que, fundado en principios de Derecho y en normas de Política Internacional, prestablecidos en nuestra América, prestó su apoyo material al gobierno del Presidente Azaña, enviándole modesta ayuda en pertrechos de guerra en momentos los más oportunos. [...] En Ginebra, México fue también explícito y rotundo". ${ }^{71}$

${ }^{69}$ Lázaro Cárdenas, Epistolario de Lázaro Cárdenas (I), México, Siglo XXI, 1974, pp. 316-319. El 3 de febrero de 1938, Cárdenas escribió a Fabela para hacerle partícipe de esta impresión: "Estoy convencido de que si no hubiera consentido en seguir la política tímida que marcó el Comité de No Intervención, los asuntos de España habrían tomado otro giro más favorable para la causa de la legalidad; pero, desgraciadamente, no ha estado en nuestra mano definir esas situaciones, aunque sí hemos tenido la satisfacción de haber hecho todo cuanto las circunstancias han tolerado”. Lázaro Cárdenas, Epistolario de Lázaro Cárdenas (I), México, Siglo XXI, 1974, pp. 321-324.

${ }^{70} \mathrm{Al}$ respecto, véase Enrique Moradiellos, El reñidero de Europa: las dimensiones internacionales de la Guerra Civil española, Barcelona, Península, 2001, 302 pp.

${ }^{71}$ Isidro Fabela, Por un mundo libre, México, Secretaría de Educación Pública, 1943, pp. 59-72. También en Matesanz (comp.), México y la República Española, pp. 93-96. 
Años después, el 26 de julio de 1958, Isidro Fabela pronunció un discurso en la embajada de España en México con motivo de la condecoración que le fue otorgada por el gobierno de la República Española, por acuerdo de su presidente Diego Martínez Barrio. Aquella insignia recibida del exilio español era entendida por Fabela como un "símbolo y recuerdo de un capítulo imperecedero no sólo de los anales de España, sino en la historia personal de mi vida”. Durante su alocución, rememoró las ya mencionadas instrucciones del presidente Cárdenas antes de su partida hacia Ginebra,

que armonizaban totalmente con mi educación de jurista, con mi ética ciudadana y con mi patriotismo a la vez mexicano y humanitario". "Cuando llegué a Ginebra -recordó Fabela- me apresté a defender a la España republicana" [...] Se trataba de España, de España que palpita en mis venas por la sangre de mis ancestros. [...] por ley y por amor, a España la defendí contra todo y contra todos, a sabiendas de que nuestro quijotismo del más puro ideal libertario resultaría estéril ante la actitud egoísta, medrosa y torpe de la Liga, pero convencido también de que realizábamos un acto estrictamente legalista y justiciero en sus principios.

Después, y de sus múltiples valoraciones, destacamos el siguiente entrecomillado, donde Fabela advirtió del carácter internacional de aquella guerra española aparentemente civil y nacional: "Me enfrenté, a nombre de México y de los derechos conculcados de un Estado miembro, no solamente contra los totalitarios del Eje, que invadieron con sus ejércitos el que debiera ser para ellos sagrado territorio de un país independiente, sino contra la incomprensión de las grandes potencias, que debiendo ser aliadas y defensoras de las instituciones de la República agredida, se transformaron en sus victimarias, [...] sosteniendo el absurdo de que la guerra en España era civil y no internacional". ${ }^{72}$ Para entonces, y como se ha dicho más arriba, la España de Franco, con la complicidad de las potencias occidentales, ya contaba con sillón propio en las Naciones Unidas. La Guerra Fría imponía su ley, y muchos países

72 Memoria de la Secretaría de Relaciones Exteriores, 1958, México, SRE, 1959, p. 21. 
democráticos -Estados Unidos, entre ellos- hicieron de Franco su perfecto aliado, máxime después de creerse el gran centinela de Occidente contra del avance comunismo soviético y "dueño" de un país geoestratégicamente muy rentable: España, punta de Europa y puente natural entre el Mediterráneo y el Atlántico.

\section{c) La lucha de México para evitar el ingreso de España en las} Naciones Unidas

A pesar de que los intentos de la delegación mexicana en Ginebra en favor de la República española resultaron en vano, por cuanto la España de Azaña no recibió el esperado apoyo de la Liga, tan sólo unos años después, otro grupo de diplomáticos mexicanos, dirigido desde Los Pinos por el presidente Manuel Ávila Camacho y encabezado para la ocasión por el diplomático Luis Quintanilla, tuvo de nuevo la oportunidad de salir en defensa de la causa republicana española. ${ }^{73}$ Hablamos de la Conferencia de San Francisco de 1945, que gestó las condiciones de paz en aquellos tiempos de posguerra y, entre otras, reunió las bases para la creación de un nuevo organismo internacional: la Organización de las Naciones Unidas. La segunda gran guerra estaba a punto de expirar con la consiguiente derrota del nazi-fascismo. En ese entonces, las circunstancias se dieron para que la diplomacia mexicana escribiera una nueva página en la larga biografía del republicanismo español, en ese entonces marcado por la huella del exilio y la dictadura franquista. Con base en ello, en 1975 Manuel Tello Macías recordó a García Robles -punto 6 de su documento- la importancia crucial de resaltar "nuestra lucha en el seno de las Naciones Unidas para evitar que España fuera admitida como miembro de esa Organización”, y puntualizó después que su embajador en la

${ }^{73}$ Abdón Mateos, "Tiempos de guerra, tiempos de desesperanza. La política de Ávila Camacho hacia España y el exilio republicano en México, 1940-1943”, Historia Mexicana, vol. 54, núm. 2, octubre-diciembre de 2004, pp. 405-443; Carlos Sola Ayape, "De la esperanza al desencanto: el exilio español en el México de Manuel Ávila Camacho (1940-1946)”, Historia del Presente, núm. 22, 2013, pp. 57-74. 
ONU debía revisar especialmente "las numerosas intervenciones de Luis Quintanilla".

A este respecto, y de todas ellas, ninguna como aquélla que Quintanilla pronunció en San Francisco el 19 de junio de 1945, ${ }^{74}$ donde dejó "claramente sentado" el criterio de México con respecto al párrafo 2 del capítulo in del reglamento constitutivo de la onu, que contemplaba las características que debían reunir los países que quisieran ingresar en este organismo de nueva creación. La postura mexicana fue defensora de la privación del derecho de ingreso no sólo a los países "vencidos del Eje" -Alemania, Italia y Japón-, sino también a los "gobiernos impuestos de alguna manera por las fuerzas militares del Eje”. ${ }^{75}$ Aquellas palabras parecían estar en consonancia con los tiempos que tocaba vivir; se había padecido la guerra más devastadora que el ser humano hubiera conocido hasta entonces, aunque aún se desconocía lo que habría de suceder semanas después en Hiroshima y Nagasaki. Por eso, la importancia de aquellas palabras de Quintanilla estriba en que la declaratoria formulada por la delegación mexicana fue finalmente aprobada y elevada a rango normativo en el reglamento constitutivo de las Naciones Unidas. ${ }^{76}$ La sanción contra los países del Eje y sus "gobiernos impuestos" acabaría siendo una realidad y, en consecuencia, un gran triunfo de la diplomacia mexicana.

De cualquier forma, el alegato de Quintanilla tuvo un claro destinatario, es decir, aquel caudillo que tras la guerra había hecho de España su gran cuartel. ${ }^{77} \mathrm{He}$ aquí el testimonio de este diplomático

${ }^{74}$ Véase Matesanz (comp.), México y la República Española, pp. 123 y 124.

${ }^{75}$ En un afán de concreción, Quintanilla aclaró lo siguiente: “Al decir esto, nos referimos no sólo al Gobierno títere de Manchukuo y al Gobierno impuesto por el Japón en China, sino también, más cerca de nosotros, las Repúblicas de América Latina, al Gobierno de España”.

${ }^{76}$ El texto literal de aquella declaración del 19 de junio de 1945 fue el siguiente: "La Delegación de México tiene entendido que el párrafo del capítulo III no puede ser aplicado a aquellos Estados cuyos regímenes han sido establecidos con la ayuda de fuerzas militares pertenecientes a los países que han hecho la guerra contra las Naciones Unidas, mientras que tales regímenes estén en el poder”. Véase Matesanz (comp.), México y la República Española, p. 128.

77 En su calidad de jefe del Estado, la ley Constitutiva de Cortes del 17 de julio de 1942 acabó por otorgar a Franco "la suprema potestad de dictar normas 
mexicano, que tanto recordaría a las aludidas intervenciones de Isidro Fabela en el foro internacional de Ginebra: "Es un hecho bien conocido que las fuerzas militares de la Italia fascista y de la Alemania nazi intervinieron abiertamente para colocar a Franco en el poder. Y dado que ésta es una guerra para erradicar los últimos vestigios del Eje [...] no deja de ser razonable pedir que no se permita participar en ninguna conferencia o Sociedad de Naciones Unidas a ningún gobierno impuesto sobre nación alguna por las fuerzas militares del Eje".

Al paso de su argumentación, Quintanilla fue claro en sus palabras siguientes, buscando causas y causantes en el asunto de la llamada Spanish question: "La guerra de Europa se ha ganado. Mussolini ya no existe y el propio Hitler ha desaparecido. Por fin podemos hablar sin miramientos. Ahora, sin poner en peligro el curso de las operaciones militares europeas, podemos decir toda la verdad". Para añadir lo siguiente: "Y la verdad histórica, Sr. Presidente, es que la ayuda militar dada a Franco por las legiones de Mussolini y el poderío aéreo de Hitler es el principal motivo de que la República de España no esté representada aquí. Además, es irónico que la caída de Hitler y Mussolini sirva para consolidar la posición de Franco en el mundo de la posguerra".

Ironías al margen, la justificación, en esta ocasión a modo de recomendación a sus pares, se escribió de esta forma. Palabras de Quintanilla: “Mussolini y Hitler, los protectores militares de Franco, han dejado de existir, pero sostenemos que su desaparición no puede borrar de manera retrospectiva y automática los pecados de los hombres a quienes ayudaron a colocar en el poder”. Asimismo, aseveró: "España fue una de las primeras víctimas del fascismo internacional y los cientos de miles de héroes que lucharon y murieron allí por la causa de la democracia fueron en realidad los primeros aliados combatientes de las Naciones Unidas. [...] la España republicana fue en realidad nuestro primer aliado. En esta

jurídicas de carácter general [...], radicando en él de modo permanente las funciones de Gobierno, sus disposiciones y resoluciones [...], aunque no vayan precedidas de la deliberación del Consejo de Ministros cuando razones de urgencia así lo aconsejen”. 
hora de triunfo, no debe pasar a ser un amigo olvidado". ${ }^{78} \mathrm{Al}$ respecto, y en palabras de Alfonso García Robles, quien formara parte de la delegación mexicana en San Francisco, "haciendo sus deberes, México había ocupado uno de los primeros lugares de las llamadas pequeñas naciones [y] puede tener la satisfacción de ser una de las naciones que más valiosa aportación hicieron al respecto". ${ }^{79}$

Recordemos que una de las principales consecuencias de la Conferencia de San Francisco, y ante la sanción moral que mereció el franquismo, fue la reconstrucción de las instituciones republicanas españolas -República y Gobierno- en la ciudad de México. ${ }^{80}$ El hecho no pasó desapercibido para uno de los grandes artífices de aquel suceso: el presidente de México. Así, con motivo de la lectura de su penúltimo Informe de Gobierno, en septiembre de 1945, Ávila Camacho recordó: "El 17 de agosto último, con la anuencia de nuestro Gobierno, que concedió las inmunidades y prerrogativas inherentes al acto, las Cortes de la República Española se reunieron en el salón de Cabildos del gobierno del Distrito Federal, y el 26 del mismo mes, por aprobación del Presidente de

78 Unas semanas antes, comenzando abril del 45, el exilio republicano español publicó un documento titulado La Junta Española de Liberación ante la Conferencia de San Francisco de California. Con este elocuente título, se quiso apelar a la "responsabilidad histórica" de las naciones concurrentes en esta ciudad californiana, con el propósito de que tuvieran en cuenta "el caso especialísimo de España”. En aquel pliego de 11 puntos se llegó a sentenciar, tal y como era de prever, que España había sido "la primera nación agredida" y la primera en conocer "los efectos horribles de la guerra totalitaria", y que el régimen franquista era producto de "una cruenta guerra civil favorecida y alentada por la Italia del duce y la Alemania del führer". Era claro que el delegado Quintanilla no sólo conocía dicha publicación, sino que utilizó sus tesis como base en la sustentación de su discurso. En este rubro, y con respecto al régimen franquista, era clara la sintonía entre el exilio español y el gobierno de Manuel Ávila Camacho.

${ }^{79}$ Alfonso García Robles, La conferencia de San Francisco y su obra, México, Segundo Congreso Mexicano de Ciencias Sociales, 1946, pp. 11, 16 y 18. Véase también Alfonso García Robles, El mundo de la postguerra: de la carta del Atlántico a la conferencia de San Francisco, México, Secretaría de Educación Pública, 1946, 746 pp.

${ }^{80}$ Sobre los entresijos de esta coyuntura, véase Mari Carmen Serra Puche, José Francisco Mejía Flores y Carlos Sola Ayape (eds.), 1945, entre la euforia y la esperanza: el México posrevolucionario y exilio republicano español, México, FCE/UnAm, 2014, 380 pp. 
la República Española, quedó constituido el Gobierno de la misma". ${ }^{81}$ Meses después, el 9 de febrero de 1946, en una sesión plenaria de la asamblea general de la onu el delegado mexicano Roberto Córdova hizo al respecto esta valoración en voz alta: "Mi país estima que el Gobierno republicano de España jamás ha dejado de existir. Nunca aceptaremos que la intervención de los países fascistas pueda arrebatar el Gobierno republicano su poder y jurisdicción”. Agregó esta consideración: "México ofreció cordialmente su hospitalidad al único Gobierno que, legal y justamente, representa al pueblo español". ${ }^{82}$

\section{MÉXico y SUS LAZOS CON EL PUEblo ESPAÑOL}

En otro orden de cosas, resulta cuando menos notorio que una de las recomendaciones que desde Tlatelolco se hizo llegar al embajador Alfonso García Robles tenía que ver con la necesidad de resaltar en sus alocuciones "los lazos que unen a México con el pueblo y la cultura española" (punto 11 del documento de Tello Macías). A decir verdad, no se especificaba qué se entendía por pueblo español o a cuál de los dos pueblos se hacía referencia: si el que vivía en territorio peninsular o el que se encontraba sobreviviendo en el vasto e indefinido territorio de la España peregrina, esto es, en el exilio. Sin embargo, era palpable el interés de la SRE por mencionar a ese pueblo español -claro estaba que el recordatorio era para el que vivía en esa España al sur de los Pirineos-, como si se

${ }^{81}$ Ante el Congreso de la Unión, el presidente mexicano justificó su decisión por "su tradicional amistad hacía el noble pueblo español" e hizo dos importantes recordatorios: primero, que su gobierno se complacía en continuar con el Gobierno republicano español "las felices y cordiales relaciones que les han unido siempre” -algo que arrancó los aplausos de los congresistas-y, segundo, que, en virtud de la interpretación dada al artículo cuarto de la Carta de San Francisco, España -la franquista- no podría ingresar en la Organización Internacional, "mientras prevalezca en su territorio el régimen que en él funciona”. Diario de los Debates de la Cámara de Diputados del Congreso de los Estados Unidos Mexicanos, XXXIX Legislatura, año III, tomo I, núm. 2, sábado, 1 de septiembre de 1945.

82 Véase Matesanz (comp.), México y la República Española, pp. 130 y 131. 
tratara de una especie de disculpa por todo cuanto México estaba haciendo en favor de los derechos humanos, de la paz y de la seguridad internacional por más que esto pareciera un ejercicio atentatorio contra España y los españoles. ${ }^{83}$

Matices al margen, sí es importante señalar que el concepto "pueblo español" siempre estuvo presente en el discurso oficial del presidencialismo mexicano, a decir verdad, más como recurso retórico que como preocupación política. ${ }^{84}$ Así, se hizo sentida la necesidad de explicar que la estrategia mexicana en contra de la España franquista era por razones estrictamente políticas o jurídicas y, en consecuencia, que el plan nada tenía que ver con la sociedad española en su conjunto. Así de México hacia España; así del régimen franquista hacia el pueblo mexicano, donde también fue denominador común echar mano de este tipo de alusiones, esto es, de que los españoles estaban plenamente identificados con los mexicanos, aunque no con sus dirigentes, ni con el régimen posrevolucionario imperante. ${ }^{85}$ De hecho, esta valoración compartida quedó en evidencia en toda su dimensión durante las semanas previas y posteriores al restablecimiento de las relaciones bilaterales entre ambos países (28 de marzo de 1977). Los discursos oficiales -muchos de ellos cargados de excesiva retórica-se nutrieron

${ }^{83}$ Por momentos, aquello tuvo sus semejanzas con lo acontecido en diciembre de 1955, cuando el entonces embajador de México en las Naciones Unidas, Rafael de la Colina, tras dar a conocer la abstención de su país en la votación sobre el ingreso de España en este organismo internacional, declaró que "estaba persuadido de que el pueblo español entenderá el motivo de nuestra abstención”. Memoria de la Secretaría de Relaciones Exteriores, 1955 (II), México, SRE, 1956, pp. 31-33.

${ }^{84}$ Véase, a modo de ejemplo, Carlos Sola Ayape, "El manejo discursivo del pasado en el restablecimiento de las relaciones entre España y México”, En-claves del Pensamiento, vol. I, núm. 1, 2007, pp. 173 y 174.

${ }^{85}$ La distinción entre pueblos y gobiernos acabó siendo uno más de los tantos tópicos. Véase el siguiente ejemplo, tras consumarse el ingreso de España en la ONU, a pesar de la abstención de Bélgica y México: "Ante todo, es preciso decir serenamente que se trata de una actitud adoptada por los Gobiernos belga y mejicano, no por los pueblos de ambas naciones, pues se da en ellos la fundamental circunstancia de que es precisamente a España, 'madre de naciones', a la que ambos deben su existencia nacional”. Luis García Arias, "La admisión en bloque en la onu y el ingreso de España”, Revista de Política Internacional, núm. 24, 1955, p. 41. 
de esta idea central, según la cual ambos pueblos nunca estuvieron distanciados por más que sus gobiernos no mantuvieran relaciones diplomáticas a nivel de las altas esferas oficiales. ${ }^{86}$

En la coyuntura histórica que aquí se analiza, resulta relevante la recuperación de algunos fragmentos, donde dirigentes mexicanos tuvieron muy presente en sus comparecencias públicas a ese "pueblo español". Comenzando por el presidente Echeverría, hay que decir que el 5 de octubre de 1975 -tan sólo unos días después de su carta remitida al secretario general de la onU para solicitar, entre otras medidas urgentes, la expulsión de España de la organización-, se reunió con 40 representantes de alumnos egresados del Colegio de Madrid de la capital mexicana, todos ellos hijos de españoles de ascendencia republicana del exilio. He aquí sus palabras, no exentas de lirismo y de clara evocación a aquellos escritores españoles de la Generación del 98: "Nos interesa España porque la queremos y nos duele España; es parte de nosotros mismos, trasplantada aquí porque su cultura es gran parte de nuestra cultura; porque es nuestro puente con Europa; por la sangre común de nuestros pueblos" ${ }^{87}$

En la misma línea, ese mismo 5 de octubre, José López-Portillo -el tapado destapado de Echeverría-, ${ }^{88}$ con motivo de su toma de

${ }^{86}$ Sirva como ejemplo el documento que se publicó para la ocasión titulado Cuatrocientos años de hermandad entre España y México (sin autor, Madrid, 1977), con el fin de "dar una imagen sinóptica del andar común de mexicanos y españoles desde antes de 1519 ".

${ }^{87}$ Y añadía: “[...] y porque ante peligros de que esta búsqueda de libertad de democracia, tan incipiente y tan defectuosa que tenemos en México en un camino tan largo, se pudiera ver frustrado nuestro proceder democrático por una cosa semejante, como pasó en Chile”. Matesanz (comp.), México y la República Española, p. 424. Unos días antes, el 29 de septiembre, Echeverría había recibido en la residencia oficial de Los Pinos a una representación de exiliados españoles, donde insistió en la idea de que los "excesos de Franco" atentaban contra la paz. El Nacional, 29 de septiembre de 1975, p. 8.

${ }^{88}$ El 27 de septiembre de 1975, fecha en que precisamente tuvieron lugar los cinco fusilamientos mencionados, el diario $A B C$ publicó un artículo sobre México, con el fin de caracterizar a su régimen político, en ese entonces, bajo la dirección del presidente Luis Echeverría. Entre otras cosas, se dijo que el Revolucionario Institucional era un partido que, además de controlar las elecciones, designaba "al candidato para la presidencia de la República, conocido como el 'tapado'”. $A B C$, 27 de septiembre de 1975 , p. 20. 
protesta como candidato del PRI a las elecciones presidenciales del año siguiente, dedicó estas palabras al asunto estelar del momento. He aquí el testimonio del que sería meses después nuevo presidente de México: "Lamentamos profundamente que ahora una de nuestras raíces no acierte a librarse del fascismo y el garrote vil. Nos da dolor. Formulamos votos porque el entrañable pueblo español rescate una vez más de las fuerzas oscuras su dignidad y su orgullo. En ese momento, México estará presente". ${ }^{89}$ De nuevo, la misma evocación al dolor por esa España cautivada por el franquismo, así como el mismo recordatorio al pueblo español.

De hecho, cuatro días después, el 9 de octubre, aquel candidato del Revolucionario Institucional iniciaba su campaña política en Querétaro; entre otras cosas, López-Portillo también hizo referencia al caso español: "No otra cosa hace el régimen político de la Revolución Mexicana cuando afirma su solidaridad con el pueblo democrático español, cuando congruente no sólo con las mejores tradiciones históricas del pueblo mexicano, sino también con las decisiones más lúcidas de las Naciones Unidas, condena los abusos cometidos contra la dignidad humana por un régimen político que, de acuerdo con un dictamen de las propias Naciones Unidas, tuvo obvias y evidentes vinculaciones con los países del Eje". Para añadir después lo siguiente: "Al definir México su posición respecto del caso de España no solamente toma una posición de vanguardia $[\ldots]$, sino también ayuda a reafirmar nuestra propia definición histórica. [...] Nuestra guerra no es contra España, sino contra los malos españoles". ${ }^{90}$ Bien sabía López-Portillo que de ganar las elecciones -algo que nadie ponía en duda-, él habría de ser el elegido para normalizar las relaciones diplomáticas con España y con los "buenos" españoles. ${ }^{91}$

${ }^{89}$ El Nacional, 6 de octubre de 1975, pp. 7 y 8.

${ }^{90}$ El Nacional, 10 de octubre de 1975, p. 7.

91 Durante la Guerra Civil española, la sociedad mexicana también quedó atrapada en el maniqueísmo planteado entre los buenos y los malos españoles. Para la ocasión, y como era de prever, para los sectores afines al oficialismo y al cardenismo en general los buenos era los republicanos. "Cambiamos gachupines por buenos españoles”, se leía en El Popular (4 de abril de 1939, p. 4), tan sólo tres días después de que Franco diera por conclusa la guerra. Véase en Inmaculada 
Y, por último, y por recoger un último testimonio de los muchos que podrían destacarse, el 20 de noviembre del 75, día de la muerte de Franco, que coincidió con una nueva celebración del aniversario de la Revolución Mexicana, Mario Moya Palencia, entonces secretario de Gobernación en el gabinete de Luis Echeverría, dijo esto ante los medios de comunicación: "Nosotros tenemos un gran respeto, una gran admiración por el pueblo español. El rechazo al gobierno franquista nunca ha significado por parte de México, de ninguna manera, una negación de sus raíces, de sus relaciones, de su auténtica vinculación con los españoles". Asimismo, y sobre las futuras relaciones con España, llegó a decir "que vincularán aún más a México con ese pueblo valeroso que, estoy seguro, resurgirá pronto a la vida plena en la libertad y para la dignidad". ${ }^{92}$ Precisamente, esta idea última también estuvo presente en el documento que recibió García Robles desde Tlatelolco -punto 12-, donde se instaba a recordar que el presidente Echeverría hacía votos por una "reafirmación de fe en el futuro de España libre y soberana". ${ }^{93}$

No quisiéramos cerrar este apartado sin antes recuperar las declaraciones de una de esas voces disidentes de aquel México de mediados de los años setenta. Si el Revolucionario Institucional dominaba de forma absoluta el panorama político y electoral mexicano, no tuvo sin embargo el monopolio exclusivo de la ideología. Recordemos que, en la sesión del 30 de septiembre de 1975, con motivo de la reunión que tuvo lugar en el Congreso de la Unión para cerrar filas en torno al presidente Echeverría, una voz disímil se alzó sobre el resto: la de Fernando Estrada Sámano. De

Cordero Olivero, El espejo desenterrado. España en México, 1975-1982, Sevilla, Fundación El Monte, 2005, p. 29.

${ }^{92}$ El Nacional, 21 de noviembre de 1975, p. 7.

${ }^{93}$ El 31 de marzo de 1977, tres días después de la normalización de las relaciones hispano-mexicanas, el entonces secretario de Relaciones Exteriores mexicano, Santiago Roel García, explicó que la razón de aquella exitosa operación se encontraba, entre otras, en "el deseo de los pueblos mexicanos y español" y en la "gran voluntad y un gran afecto de los gobiernos español y mexicano para establecer las relaciones”. Archivo Histórico Genaro Estrada, expediente III-5251-1 (segunda parte). 
entrada, este diputado de Acción Nacional advirtió que el llamamiento del presidente Echeverría a las Naciones Unidas para que los países miembros interrumpieran "totalmente" no sólo sus relaciones diplomáticas y económicas, sino también las comunicaciones ferroviarias, marítimas, aéreas, postales, telegráficas, radioeléctricas y otros medios de comunicación, quedaba desvirtuado al tomar el gobierno mexicano "medidas unilaterales y desproporcionadas contra ciudadanos y bienes españoles". Por eso, ante el deseo del presidente mexicano de imponer un verdadero bloqueo contra España $-y$, por ende, contra el pueblo español, a la postre, quien habría de ser la verdadera víctima del mismo-, el diputado panista hizo la siguiente valoración personal: "Lo que pudo ser un ejemplo de cristalización en el anhelo de una autoridad mundial, queda en un contrasentido que poco tiene de ejemplar". ${ }^{94}$

Frente a este diagnóstico, y teniendo presentes los luctuosos sucesos de Tlatelolco y del Jueves de Corpus -2 de octubre de 1968 y 10 de junio de 1971, respectivamente- este diputado fue más allá al advertir de la "incongruencia del Gobierno [mexicano] que exige y aplica, antes de que la onu tome una decisión en un juicio imparcial y objetivo, sanciones unilaterales por los cinco fusilados en España, cuando en su propia jurisdicción interna no señala ni castiga a los culpables de represiones". Por eso, y además del recordatorio a esta "violencia innecesaria”, terminó por recordar al presidente Echeverría que el pueblo español no necesitaba de ningún salvador externo. He aquí su testimonio final: "Acción Nacional expresa su confianza en la centenaria capacidad del pueblo español para salvarse por sí mismo". ${ }^{95}$

\section{VALORAciones Finales}

Afrontamos la recta final de este manuscrito, recordando, tal y como se ha señalado más arriba, que aquel 29 de septiembre de 1975 -día de la protesta en las Naciones Unidas del embajador

${ }^{94}$ Véase Matesanz (comp.), México y la República Española, p. 421.

${ }^{95}$ Loc. cit. 
español De Piniés-, el representante permanente de México en este organismo, Alfonso García Robles, pasaba de nuevo a la acción, en esta ocasión para remitir una nueva carta al secretario general del organismo, ahora de su puño y letra, con la intención de salir al paso de las "acusaciones e insultos injustificables contra el Jefe del Estado mexicano", vertidos por el representante "del régimen que preside en España el General Francisco Franco" ${ }^{96}$ Además de lamentar el tono de la epístola, García Robles consideró "indispensable recalcar que la posición del actual presidente de México, Sr. Luis Echeverría Álvarez, en lo que atañe al régimen franquista, no tiene nada de personal, sino que, por el contrario, refleja fielmente la posición invariable de las siete administraciones públicas sexenales que ha habido en mi país desde la guerra civil española". Era evidente que en este fragmento se encontraban muy presentes las valoraciones hechas desde Tlatelolco por Tello Macías, Director en Jefe para Asuntos Políticos Bilaterales de México, así como los doce puntos que venían a reflejar la postura mexicana sobre la España franquista durante cuatro décadas.

Para la ocasión, García Robles anexó a su carta "no una serie de elucubraciones periodísticas o insinuaciones malévolas", sino simplemente "la parte pertinente del acta oficial" de la tercera sesión -efectuada el 19 de junio de 1945- de la comisión primera de la Conferencia de San Francisco que tuvo a su cargo la consideración y aprobación de lo que se traduciría después en los artículos 3 y 4 de la Carta de las Naciones Unidas que se ocupaban de los Miembros de la Organización. De nuevo, el recuerdo al embajador Luis Quintanilla y a una de las recomendaciones hechas desde Tlatelolco ese mismo día, y de la que hemos dado puntual cuenta en páginas precedentes. Ante semejante soporte documental, García Robles no tuvo reparo alguno en avalar sus argumentos con el siguiente testimonio, con el fin último de disipar cualquier sombra de sospecha sobre los posibles "reflejos emotivos" de su presidente: "A la luz de las declaraciones formuladas en 1945 por el Representante de México en la Comisión I de la Conferencia de San Francisco que se reproducen en el acta que acabo de citar [...] se

${ }^{96}$ Véase Matesanz (comp.), México y la República Española, pp. 415 y 416. 
entenderá bien por qué dije al principio que el mensaje del Presidente Echeverría al Secretario General no se debe a reflejos emotivos, sino que corresponde a la tradicional postura de México frente al caso de España". ${ }^{97}$ Una vez más, la tesis de la posición vertical se ponía sobre la mesa para evidenciar, desde el doble principio de la continuidad y congruencia, la solidez histórica, diplomática y jurídica con la que México se había manejado con respecto a la cuestión española. ${ }^{98}$

$\mathrm{Al}$ margen del encono verbal y del cruce de declaraciones entre los representantes de México y España, hay que recordar que el Consejo de Seguridad de las Naciones Unidas, sin entrar en la discusión sobre la pertinencia o no de la nota mexicana, consideraron que dicha instancia era inadecuada por tratarse de un asunto que no afectaba ni a la paz internacional ni a la seguridad de las naciones. Seguidamente, el tema se turnó a la comisión de Derechos Humanos, donde el expediente acabó siendo olvidado. ${ }^{99} \mathrm{Di}$ cho de otro modo, Echeverría no logró conseguir su anhelada meta de ser el protagonista del derrocamiento de Franco, como tampoco lograría sus propósitos personales para los que también diseñó aquella estrategia diplomática, donde tanto peso tuvo la SRE a través de Manuel Tello Macías y Alfonso García Robles. Detrás de

${ }^{97}$ Por su parte, García Robles recordó en su nota, primero, "la reacción universal de indignada reprobación que provocaron las últimas ejecuciones registradas en territorio español" y, segundo, el hecho de que el gobierno de México, "acostumbrado a predicar con el ejemplo, se esfuerza siempre en que las palabras se vean comprobadas por hechos concordantes". Estaba claro que García Robles hacía alusión explícita a la postura "vertical", secundando las directrices emitidas desde Tlatelolco.

${ }^{98}$ En este contexto, bajo ningún concepto fue casual que viera la luz la siguiente publicación: Continuidad y congruencia de la política de México ante la dictadura franquista, México, Cultura y Ciencia Política, 1975, 60 pp.

${ }^{99}$ El periódico Excélsior daba cuenta de las declaraciones del portavoz del Secretario General: "El Consejo había decidido rechazar la petición mexicana, por considerar que el foro adecuado al que había de dirigirse, dada su solicitud de aislamiento político y económico, era la tercera comisión de la Asamblea General, encargada de los asuntos económicos y sociales”. Excélsior, 1 de octubre de 1975, p. 1. Sobre estos pormenores, véase Carlos Sola Ayape, Entre fascistas y cuervos rojos: España y México (1934-1975), México, Porrúa/Tecnológico de Monterrey, 2008, p. 170. 
aquella puesta en escena, donde Echeverría pretendió mostrarse como ese líder defensor de los derechos humanos, de la paz internacional y contrario a dictadores como el general Franco -Echeverría llegó a declarar que la razón moral de su petición a la onU era la de "evitar una nueva guerra fratricida en España"-, ${ }^{100}$ se encontraba el anhelo no sólo de enterrar el luctuoso pasado que lo vinculaba con los crímenes de Tlatelolco, sino de ganar adeptos para alcanzar su sueño tras abandonar la presidencia de la República mexicana: el cargo de secretario general de las Naciones Unidas. ${ }^{101}$ Tal vez por todo esto, Alfonso García Robles fue especialmente cuidadoso al no hacer mención alguna ni a la cuestión española ni al enfrentamiento de su presidente contra Franco, con motivo de la elaboración de su libro sobre la actuación de México en el campo de las relaciones internacionales durante aquel sexenio. ${ }^{102}$

De todos modos, el destino acabaría siendo caprichoso. Tan sólo unas semanas después de lo acontecido, concretamente el 20 de noviembre de 1975, y cuando México celebraba un nuevo aniversario de su Revolución, tuvo lugar el fallecimiento de Francisco Franco. El affaire de Echeverría estaba demasiado caliente y, en consecuencia, era el momento, ahora a título póstumo, de escribir el epitafio sobre la lápida de aquel dictador. Aquel día, el ya mencionado Mario Moya Palencia hizo estas declaraciones ante los medios de comunicación: "La muerte de Franco significa la caída del último de los signos del totalitarismo nazi-fascista que envuelve toda una etapa en la vida de la humanidad en el siglo xx. Franco había sido un símbolo [...] impuesto por la fuerza de los ejércitos

${ }^{100}$ El Nacional, 30 de septiembre de 1975, p. 1.

${ }^{101}$ Recordemos que, en aquel entonces, Estados Unidos -miembro permanente del Consejo de Seguridad de la onu- estaba negociando con la España de Franco la prolongación del convenio militar firmado entre ambos países. En juego estaba el futuro de las cuatro bases militares estadounidenses en territorio español, consideradas por la Casa Blanca como esenciales para la seguridad nacional de este país americano. De ahí la defensa que los norteamericanos hicieron del principio de no intervención en este particular asunto hispano-mexicano, evidenciando su interés de que España siguiera siendo país miembro de este organismo internacional.

102 Véase Alfonso García Robles, Seis años de la política exterior de México, 19701976, México, sRe, 1976, 64 pp. 
nazi-fascistas y como producto de una sublevación militar en España”. ${ }^{103}$ No había mucho más que añadir: en materia de construcción de la memoria, la sentencia estaba echada.

De todos modos, y si de algo sirvió aquella afrenta de Echeverría en contra de Franco, fue para poner de manifiesto la cuidada ortopedia del discurso diplomático mexicano con respecto a la España franquista. Aquel documento mecanografiado que Tello Macías hizo llegar a García Robles con fecha de 29 de septiembre de 1975, con el propósito último de salir en defensa del presidente de México ante las acusaciones de la España franquista, puede ser visto como una reunión de los principios de la política exterior mexicana con respecto a la cuestión española. En pocas palabras, más de 39 años de historia concentrados en tan sólo tres cuartillas, vinculadas a la figura de Luis Echeverría, el mismo que tampoco pudo lograr, como fue su intención, el restablecimiento de las relaciones diplomáticas con la España del rey Juan Carlos. Si Franco había sido el responsable de que el vínculo hispano-mexicano permaneciera quebrado, tras la muerte del dictador ese impedimento se llamó Luis Echeverría. La normalización de las relaciones entre México y España tuvo lugar en la primavera de 1977, de la mano del nuevo presidente, José López-Portillo, quien, dicho sea de paso, supo manejar hábilmente su ascendencia genealógica española, concretamente de la localidad navarra de Caparroso.

\section{BiBLIOGRAFÍA}

Alegre, Sergio, El cine cambia la historia: las imágenes de la División Azul, Barcelona, PPU, 1994.

Armero, José Mario, La política exterior de Franco, Barcelona, Planeta, 1978. Bassols, Narciso, Obras, México, FCE, 1964.

Brading, David, Los orígenes del nacionalismo mexicano, México, Era, 1993.

Calzada, Manuel de la, "España y los organismos especializados de la onu”, Revista de Política Internacional, núm. 6, 1951, pp. 109-115. 
Cárdenas, Lázaro, Epistolario de Lázaro Cárdenas (I), México, Siglo XXI, 1974.

— Epistolario de Lázaro Cárdenas (II), México, Siglo XXI, 1974-1975.

—, Ideario político, México, Ediciones Era, 1972.

—, Obras I - Apuntes, 1913-1940 (I), México, Universidad Nacional Autónoma de México, 1972.

Continuidad y congruencia de la política de México ante la dictadura franquista, México, Cultura y Ciencia Política, 1975.

Cordero Olivero, Inmaculada, El espejo desenterrado. España en México, 1975-1982, Sevilla, Fundación El Monte, 2005.

Diario de los Debates de la Cámara de Diputados del Congreso de los Estados Unidos Mexicanos, XXXIX Legislatura, año III, tomo I, núm. 2, sábado 1 de septiembre de 1945.

Eslava Galán, Juan, Los años del miedo, Barcelona, Planeta, 2008.

Fabela, Isidro, Cartas al presidente Cárdenas, México, Altamira, 1947.

-, Por un mundo libre, México, Ediciones de la Secretaría de Educación Pública, 1943.

— y Luis I. Rodríguez, Diplomáticos de Cárdenas: una trinchera mexicana en la Guerra Civil (1936-1940), Madrid, Trama Editorial, 2007.

Fernández, Antonio y Juan Carlos Pereira, "La percepción española de la onu (1945-1962)", Cuadernos de Historia Contemporánea, núm. 17, 1995, pp. 121-146.

García Arias, Luis, "La admisión en bloque en la ONU y el ingreso de España”, Revista de Política Internacional, núm. 24, 1955, pp. 21-43.

García Robles, Alfonso, El mundo de la postguerra: de la carta del Atlántico a la conferencia de San Francisco, México, Secretaría de Educación Pública, 1946.

— L L L conferencia de San Francisco y su obra, México, Segundo Congreso Mexicano de Ciencias Sociales, 1946.

— Seis años de la política exterior de México, 1970-1976, México, SRE, 1976.

Gil Pecharromán, Julio, Con permiso de la autoridad. La España de Franco (1939-1975), Madrid, Ediciones Temas de Hoy, 2008.

Gómez Villanueva, Augusto, Nacionalismo revolucionario. Orígenes socioeconómicos de la doctrina internacional de la Revolución Mexicana, México, Miguel Ángel Porrúa, 2010. 
Ibn Azuz Hakim, Mohammad, La actitud de los moros ante el Alzamiento: Marruecos, 1936, Málaga, Algazara, 1997.

Landavazo, Marco Antonio, "La crisis entre México y España en el ocaso del franquismo", Secuencia, núm. 38, mayo-agosto de 1997, pp. 95-120.

Lleonart y Amsélem, Alberto José, "El ingreso de España en la onu: obstáculos e impulsos", Cuadernos de Historia Contemporánea, núm. 17, 1995, pp. 101-119.

—_ "España y la onu: la 'cuestión española' (1945-1950)”, Revista de Política Internacional, núm. 152, 1977, pp. 27-45.

—, España y oNU - VI (1952-1955), Madrid, Consejo Superior de Investigaciones Científicas, 2002.

Los presidentes de México ante la Nación. Informes, manifiestos y documentos de 1821 a 1966 (IV), México, Imprenta de la Cámara de Diputados, 1966.

Loyola, Rafael, "Con Franco, la guerra y la moderación se nos atravesaron”, en Mari Carmen Serra Puche; Francisco Mejía Flores y Carlos Sola Ayape (eds.), De la posrevolución mexicana al exilio republicano español, México, FCE, 2011, pp. 161-197.

Manero, Antonio, México y la solidaridad americana: la doctrina Carranza, Madrid, Editorial Americana, 1918.

Martínez Lillo, Pedro A., "La política exterior de España en el marco de la Guerra Fría: del aislamiento limitado a la integración parcial en la sociedad internacional, 1945-1953", en Javier Tussell, Juan Avilés y Rosa Pardo (eds.), La política exterior de España en el siglo XX, Madrid, UNED-Biblioteca Nueva, 2000, pp. 323-340.

Martínez Reverte, Jorge, La División Azul: Rusia (1941-1944), Barcelona, RBA, 2011.

Mateos, Abdón, "Tiempos de guerra, tiempos de desesperanza. La política de Ávila Camacho hacia España y el exilio republicano en México, 1940-1943”, Historia Mexicana, vol. 54, núm. 2, octubre-diciembre de 2004, pp. 405-443.

Matesanz, José Antonio (comp.), México y la República Española. Antología de documentos, 1931-1977, México, Centro Republicano Español de México, 1978.

—_ "De Cárdenas a López Portillo: México ante la República Española, 1936-1977”, Estudios de Historia Moderna y Contemporánea, vol. VIII, 1980.

Memoria de la Secretaría de Relaciones Exteriores, 1955 (II), México, SRE, 1956. 
Memoria de la Secretaría de Relaciones Exteriores, 1958, México, SRE, 1959.

Memoria de la Secretaría de Relaciones Exteriores, septiembre de 1940-agosto de 1941, México, SRE, 1941.

Mesa, José Luis de, Los moros y la Guerra Civil española, Madrid, Actas, 2004.

Miravitlles, Jaume, Los comunicados secretos de Franco, Hitler y Mussolini, Barcelona, Plaza \& Janés, 1977.

Moradiellos, Enrique, "Potsdam, 1945: el franquismo en entredicho", Claves de razón práctica, núm. 92, 1999, pp. 54-60.

- El reñidero de Europa: las dimensiones internacionales de la Guerra Civil española, Barcelona, Península, 2001.

Moreno Juliá, Xavier, La División Azul. Sangre española en Rusia, 1941-1945, Barcelona, Crítica, 2006.

Ochoa Bilbao, Luis, "Intelectuales y política exterior: el caso mexicano, siglos xx y xxı”, en Paulino Arellanes Jiménez (coord.), Escenarios, actores y conflictos internacionales, México, Grupo Editorial Patria, 2008.

Ojeda Revah, Mario, México y la guerra civil española, México, Turner, 2005. Payne, Stanley G., 40 preguntas fundamentales sobre la Guerra Civil, Madrid, La Esfera de los Libros, 2006.

— Franco y Hitler: España, Alemania, la Segunda Guerra Mundial y el holocausto, Madrid, La Esfera de los Libros, 2008.

y Delia Contreras, España y la Segunda Guerra Mundial, Madrid, Editorial Complutense, 1996.

Pensamiento político de Franco (I), Madrid, Ediciones del Movimiento, 1975.

Pons Ràfols, Xavier (coord.), España y la ONU: 50’ aniversario, Barcelona, Icaria, 2005.

Portero, Florentino, Franco aislado. La cuestión española (1945-1950), Madrid, Aguilar, 1989.

Preston, Paul, Franco: Caudillo de España, Barcelona, Grijalbo, 1994.

Sánchez Andrés, Agustín y Fabián Herrera León, Contra todo y contra todos. La diplomacia mexicana y la cuestión española en la Sociedad de Naciones, Tenerife, Idea, 2011.

Sánchez Andrés, Agustín y Marco Antonio Landavazo, "México y España. Entre la ruptura y la normalización, 1975-1977”, Ciencia Nicolaita, núm. 35, agosto de 2003, pp. 13-22.

Serra Puche, Mari Carmen, José Francisco Mejía Flores y Carlos Sola Ayape (eds.), 1945, entre la euforia y la esperanza: el México posrevolucionario y exilio republicano español, México, FCE/UnAm, 2014. 
Serrano Migallón, Fernando, Con certera visión: Isidro Fabela y su tiempo, México, FCE, 2000.

Shapira, Yoram, "La política exterior de México bajo el régimen de Echeverría: retrospectiva", Foro Internacional, núm. 73, julio-septiembre de 1978, pp. 62-91.

Sola Ayape, Carlos, "El manejo discursivo del pasado en el restablecimiento de las relaciones entre España y México", En-claves del pensamiento, vol. I, núm. 1, 2007, pp. 167-189.

— Entre fascistas y cuervos rojos: España y México (1934-1975), México, Porrúa /Tecnológico de Monterrey, 2008.

-, "El presidente José López-Portillo y la reanudación de las relaciones hispano-mexicanas (marzo de 1977), Historia del Presente, núm. 16, 2011, pp. 113-126.

—, "El régimen presidencialista mexicano ante el primer franquismo (1939-1955)”, en Abdón Mateos y Agustín Sánchez-Andrés (eds.), Ruptura y transición. España y México, 1939, Madrid, Eneida, 2011, pp. 185-212.

, "Sobre fórmulas y puntos de ruptura: el manejo diplomático en la normalización de las relaciones entre México y España (19751977)", Foro Internacional, vol. 51, núm. 2 (204), 2011, pp. 271-303.

_ , "De la esperanza al desencanto: el exilio español en el México de Manuel Ávila Camacho (1940-1946)”, Historia del presente, núm. 22, 2013, pp. 57-74.

Urrea, Blas, La herencia de Carranza, México, Imprenta Nacional, 1920.

Velázquez, Olga, "La pugna por la paz y la polémica ideológica en torno al uso militar de la energía atómica”, en Alberto Enríquez Perea (coord.), Homenaje a Alfonso García Robles, Premio Nobel de la Paz en 1982, México, UNAM, 2013.

Vidal y Gadea, José Antonio, Breves notas sobre la División Azul, Alicante, García Hispán, 1991. 